\title{
THE
}

\section{Climate Variability, Oceanography, Bowhead Whale Distribution, and Iñupiat Subsistence Whaling near Barrow, Alaska}

\author{
Carin J. Ashjian \\ Stephen R. Braund \\ Robert Campbell \\ University of Rhode Island, rgcampbell@uri.edu \\ J. C. "Craig" George \\ Jack Kruse
}

See next page for additional authors

Follow this and additional works at: https://digitalcommons.uri.edu/gsofacpubs

\section{Citation/Publisher Attribution}

ASHJIAN, Carin J. et al. Climate Variability, Oceanography, Bowhead Whale Distribution, and Iñupiat Subsistence Whaling near Barrow, Alaska. ARCTIC, [S.I.], v. 63, n. 2, p. 179-194, june 2010. ISSN 1923-1245. Available at: . Date accessed: 31 oct. 2018. doi: https://doi.org/10.14430/arctic973. Available at: https://doi.org/10.14430/arctic973

This Article is brought to you for free and open access by the Graduate School of Oceanography at DigitalCommons@URI. It has been accepted for inclusion in Graduate School of Oceanography Faculty Publications by an authorized administrator of DigitalCommons@URI. For more information, please contact digitalcommons-group@uri.edu. 


\section{Authors}

Carin J. Ashjian, Stephen R. Braund, Robert Campbell, J. C. "Craig" George, Jack Kruse, Wieslaw Maslowski, Sue E. Moore, Craig R. Nicolson, Stephen R. Okkonen, Barry F. Sherr, Evelyn B. Sherr, and Yvette H. Spitz 


\title{
Climate Variability, Oceanography, Bowhead Whale Distribution, and Iñupiat Subsistence Whaling near Barrow, Alaska
}

\author{
CARIN J. ASHJIAN, ${ }^{1}$ STEPHEN R. BRAUND, ${ }^{2}$ ROBERT G. CAMPBELL, ${ }^{3}$ J.C. "CRAIG" GEORGE, ${ }^{4}$ JACK KRUSE, ${ }^{5}$ \\ WIESLAW MASLOWSKI, ${ }^{6}$ SUE E. MOORE, ${ }^{7}$ CRAIG R. NICOLSON,${ }^{8}$ STEPHEN R. OKKONEN,${ }^{9}$ BARRY F. SHERR, ${ }^{10}$ \\ EVELYN B. SHERR ${ }^{10}$ and YVETTE H. SPITZ ${ }^{10}$
}

(Received 17 March 2009; accepted in revised form 21 October 2009)

\begin{abstract}
The annual migration of bowhead whales (Balaena mysticetus) past Barrow, Alaska, has provided subsistence hunting to Iñupiat for centuries. Bowheads recurrently feed on aggregations of zooplankton prey near Barrow in autumn. The mechanisms that form these aggregations, and the associations between whales and oceanography, were investigated using field sampling, retrospective analysis, and traditional knowledge interviews. Oceanographic and aerial surveys were conducted near Barrow during August and September in 2005 and 2006. Multiple water masses were observed, and close coupling between water mass type and biological characteristics was noted. Short-term variability in hydrography was associated with changes in wind speed and direction that profoundly affected plankton taxonomic composition. Aggregations of ca. 50-100 bowhead whales were observed in early September of both years at locations consistent with traditional knowledge. Retrospective analyses of records for 1984-2004 also showed that annual aggregations of whales near Barrow were associated with wind speed and direction. Euphausiids and copepods appear to be upwelled onto the Beaufort Sea shelf during E or SE winds. A favorable feeding environment is produced when these plankton are retained and concentrated on the shelf by the prevailing westward Beaufort Sea shelf currents that converge with the Alaska Coastal Current flowing to the northeast along the eastern edge of Barrow Canyon.
\end{abstract}

Key words: bowhead whale, plankton, oceanography, Beaufort Sea, subsistence whaling

RÉSUMÉ. La migration annuelle des baleines boréales (Balaena mysticetus) au-delà de Barrow, en Alaska, favorise la pêche de subsistance des Iñupiats depuis des siècles. Les baleines boréales se nourrissent fréquemment d'agrégations de proie de zooplancton près de Barrow à l'automne. Les mécanismes qui forment ces agrégations, de même que les associations entre les baleines et l'océanographie, ont fait l'objet d'une étude au moyen d'échantillonnages sur le terrain, d'analyses rétrospectives et d'entretiens permettant de prélever des connaissances traditionnelles. Des levés océanographiques et aériens ont été effectués près de Barrow en août et en septembre des années 2005 et 2006. Des masses d'eau multiples ont été observées et un couplage étroit entre le type de masse d'eau et les caractéristiques biologiques a été noté. La variabilité à court terme en matière d'hydrographie était liée à des changements relatifs à la vitesse et à l'orientation du vent qui avaient de fortes incidences sur la composition taxonomique du plancton. Des agrégations d'environ 50 à 100 baleines boréales ont été observées au début septembre des deux années à des emplacements cadrant avec les connaissances traditionnelles. Les analyses rétrospectives des données recueillies de 1984 à 2004 ont également montré que les agrégations annuelles de baleines boréales près de Barrow étaient liées à la vitesse et à l'orientation du vent. Les euphausias et les copépodes semblaient remonter vers le plateau de la mer de Beaufort lorsque les vents étaient de l'est ou du sud-est. Un milieu alimentaire favorable est créé lorsque le plancton est retenu et concentré sur le plateau par les courants de direction ouest du plateau de la mer de Beaufort qui convergent avec le courant côtier de l'Alaska s'écoulant vers le nord-est le long de la rive est du canyon de Barrow.

\footnotetext{
${ }^{1}$ Corresponding author: Department of Biology, Woods Hole Oceanographic Institution, Woods Hole, Massachusetts 02543, USA; cashjian@whoi.edu

${ }^{2}$ Stephen R. Braund \& Associates, PO Box 1480, Anchorage, Alaska 99510, USA

${ }^{3}$ Graduate School of Oceanography, University of Rhode Island, Narragansett, Rhode Island 02882, USA

${ }^{4}$ North Slope Borough Department of Wildlife Management, PO Box 69, Barrow, Alaska 99723, USA

${ }^{5}$ Institute of Social and Economic Research, University of Alaska Anchorage, 3211 Providence Drive, Anchorage, Alaska 99508, USA

${ }^{6}$ Department of Oceanography, Naval Postgraduate School, Monterey, California 93943, USA

${ }^{7}$ NOAA/Fisheries, Office of Science \& Technology, 7600 Sand Point Way NE, Building 3, Seattle, Washington 98115, USA

${ }^{8}$ Department of Natural Resources Conservation, University of Massachusetts, Amherst, Massachusetts 01003, USA

${ }^{9}$ Institute of Marine Science, University of Alaska Fairbanks, Fairbanks, Alaska 99775, USA

${ }^{10}$ College of Oceanic and Atmospheric Sciences, Oregon State University, 104 COAS Administration Building, Corvallis, Oregon 97331, USA

(C) The Arctic Institute of North America
} 
Mots clés : baleine boréale, plancton, océanographie, mer de Beaufort, pêche de subsistance à la baleine

Traduit pour la revue Arctic par Nicole Giguère.

\section{INTRODUCTION}

Offshore waters near Barrow, Alaska, are important migratory and feeding habitat for bowhead whales (Balaena mysticetus). The annual migration brings the whales north along the coast of Alaska past Barrow during spring (AprilMay) as they move from their overwintering grounds in the northern Bering Sea to their summering grounds in the Canadian Arctic (Moore and Reeves, 1993; Moore et al., 2000). The westward and southward migration of the whales in fall (September-October) again brings them past Barrow (Moore et al., 2000; Quakenbush et al., in press). The local community harvests bowhead whales at Barrow during both spring and fall migrations to provide subsistence food (Stoker and Krupnik, 1993). Archaeological evidence indicates that whaling has been an important way of life for the native peoples of the northern Alaskan coast for centuries (Stanford, 1976; Hall et al., 1990; Krupnik and Bogoslovskaya, 1999). Because the whales pause at Barrow and other key locations to feed during their migrations, the locations of the native villages (Barrow, Kaktovik) along the northern Alaskan coast were probably selected for reliable and easy access to this important subsistence food resource.

Although bowhead whales are known to feed near Barrow, the oceanographic conditions that produce a favorable feeding environment for the whales were unknown. Bowhead whales feed on zooplankton, especially copepods and euphausiids (also called krill). Stomach contents of bowhead whales harvested by native hunters at Barrow reveal that both large copepods such as Calanus glacialis and $C$. hyperboreus and euphausiids such as Thysanoessa inermis and T. raschii are important components of the whales' diet (Carroll et al., 1987; Lowry, 1993; Lowry and Sheffield, 2002; Lowry et al., 2004). To feed efficiently, baleen whales such as the bowhead whale and the North Atlantic right whale must feed in locations where aggregations of their zooplankton prey occur in high densities (e.g., Mayo and Marx, 1990; Kenney, 2001; Baumgartner and Mate, 2003; Baumgartner et al., 2003). Such zooplankton aggregations may result from either physical mechanisms (e.g., convergence) or biological mechanisms (e.g., behavior).

The complex oceanographic conditions near Barrow include the juxtaposition of two oceanographic regions (the Chukchi and Beaufort seas) and several diverse water masses (Weingartner et al., 1998, 2005; Fig. 1). The presence of a submarine canyon (Barrow Canyon) just offshore has strong impacts on local conditions (e.g., Aagaard and Roach, 1990; Pickart et al., 2005). The dynamics of flow within Barrow Canyon are highly variable (Münchow and Carmack, 1997; Signorini et al., 1997). During summer, relatively warm, fresh water of Bering Sea and Chukchi
Sea origin (hereafter called Pacific Water, PW) is carried along the northwestern Alaska coast by the Alaska Coastal Current (Paquette and Bourke, 1974) and exits the Chukchi Sea shelf through Barrow Canyon. Both observations and numerical models have demonstrated that annual mean transports of this warm, fresh Pacific Water into the northern Chukchi Sea and along the Beaufort Sea shelf vary in response to changes in atmospheric conditions associated with the Arctic Oscillation and other long-period climatic signals (Proshutinsky and Johnson, 1997, 2001; Thompson and Wallace, 1998; Maslowski et al., 2000, 2001; Clement et al., 2005; Woodgate and Aagaard, 2005; Woodgate et al., 2005). Moreover, long-period variability in the northward transport of Pacific Water introduces variability to the fluxes of heat, salt, nutrients, and plankton to the Arctic that, in turn, affect the Arctic ecosystem.

The water masses in the study region directly influence the taxonomic composition of the zooplankton prey available to the bowhead whale. Large copepods such as $C$. glacialis are found in both Arctic and Pacific waters. Primarily from analysis of bird and mammal stomach contents, euphausiids are known to be present near Barrow (e.g., Frost and Lowry, 1984; Lowry et al., 2004). In general, however, euphausiids are rare in the Western Arctic and may not be endemic to that region (Johnson, 1958, 1963; Niebauer and Schell, 1993; Schell et al., 1998) and thus must be carried into the Arctic with Pacific Water. The abundance of euphausiids and their availability as prey to the bowhead whales near Barrow then depends on (1) the northward volume transport of Pacific Water, (2) the quantity of euphausiids in the Pacific Water and their growth and survivorship during their transit across the Chukchi Sea to the Barrow region, (3) the transit time of such water and plankton from the Bering Strait to Barrow, and (4) the existence of mechanisms that aggregate euphausiids into dense prey patches.

During 2005 and 2006, we examined physical and biological oceanographic conditions and bowhead whale distributions on the shelf near Barrow, at the Beaufort Sea shelf break, and across Barrow Canyon as part of a study investigating environmental variability, oceanography, bowhead whale distribution, and the success and resilience of Iñupiat subsistence whaling. This multidisciplinary study involves a synthesis of oceanographic observations (including whale distributions), biological and physical modeling of the ice-ocean system, retrospective analyses of factors such as whale distribution and whale prey selection relative to predictions of the modeling effort, and local knowledge of factors associated with whale distribution. Retrospective analysis and local knowledge provide greater temporal context for the observations and the associations found during this two-year period of oceanographic and whale-distribution data collection. The hypotheses of the study were that 


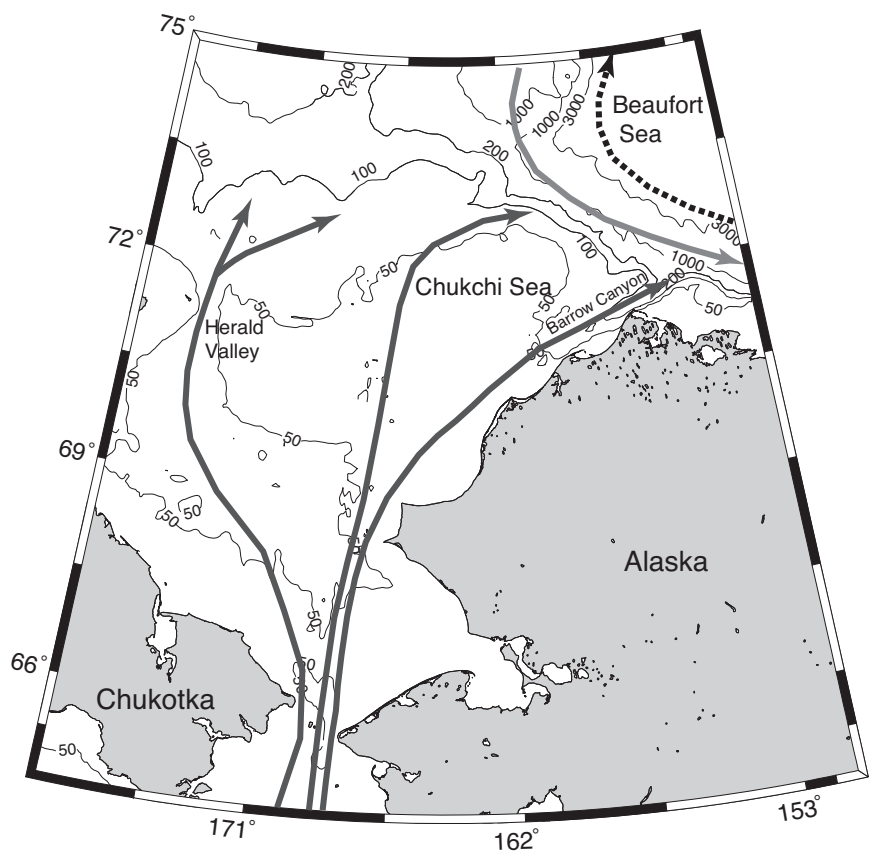

FIG. 1. Major currents in the Chukchi and Beaufort seas. Bering Sea water enters the region through the Bering Strait and flows north along three major pathways (dark gray arrows). The Beaufort Gyre is located over the Canada Basin (black dashed line). An eastward-flowing current (light gray arrow) persists along the Beaufort Sea shelf.

1) bowhead whales congregate near Barrow in late summer in response to the favorable feeding environment, 2) the formation of whale prey aggregations depends on oceanographic conditions that in turn depend on Arctic climate, and 3) Iñupiat subsistence whaling success depends on the location and timing of the whale migration and local feeding opportunities. Field surveys on the shelf near Barrow took place in late summer-early fall of 2005 and 2006, and traditional knowledge interviews with Barrow whale hunters were conducted during several trips to the community in 2006. The oceanographic measurements from those surveys are the only high-spatial resolution descriptions to date of the physical and biological oceanography of the Beaufort Sea shelf near Barrow, Alaska. Here we present an overview of our key initial findings and explain why, in spite of the range of variability in conditions in the humanbowhead-euphausiid-ocean system, whales are still reliably present each fall for Barrow hunters. This presentation is augmented by a related paper focusing on bowhead whale distribution, behavior, and stomach contents (Moore et al., 2010).

\section{METHODS}

Oceanographic fieldwork near Barrow, Alaska, was conducted from mid-August to mid-September in 2005 and 2006. This period was chosen to be close to the westward migration period of the bowhead whales yet conclude about a week before the onset of Iñupiat fall whaling at Barrow.

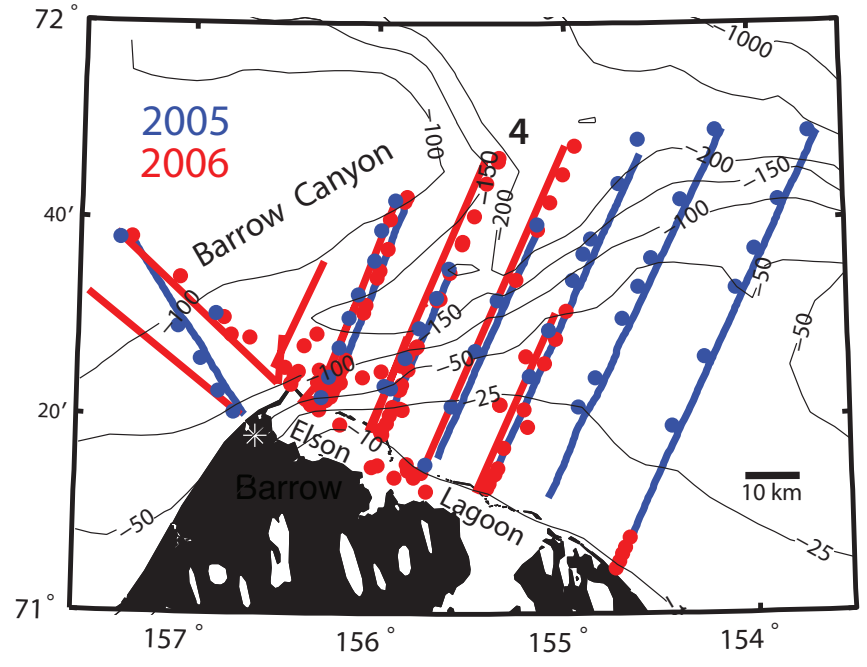

FIG. 2. Sampling locations from the 2005 and 2006 surveys. Solid lines: Continuous sampling using the Acrobat and towed ADCP. Dots represent the locations where additional sampling was done using the CTD/rosette and nets. Transect 4 is identified. Contour lines show water depth in meters.

\section{Oceanographic Sampling}

Oceanographic sampling was conducted from the 43' $\mathrm{R} / \mathrm{V}$ Annika Marie along transects oriented orthogonally to the coast or to Barrow Canyon. Transects extended from the nearshore to across the Canyon or to $\sim 150 \mathrm{~m}$ depth along the Beaufort Sea shelf break (Fig. 2), although ice limited the offshore extent of sampling on some lines and dates in 2006. The actual distribution of ice and the location of the ice edge varied markedly from day to day during the sampling period. On the outbound portion of each transect, an Acrobat towed undulating vehicle (Sea Sciences, Inc), equipped with a SeaBird 49 conductivity-temperaturedepth (CTD) sensor and a Wetlabs Eco-Triplet (chlorophyll and colored dissolved organic material (CDOM) fluorometers, optical backscatter sensor) acquired real-time measurements of water column temperature, salinity, chlorophyll fluorescence, CDOM fluorescence, and optical backscatter (suspended sediment proxy) from the nearsurface $(1 \mathrm{~m})$ to a few meters off the bottom, or to a maximum depth of $60 \mathrm{~m}$ (Table 1). Inter-profile distance was $\sim 150 \mathrm{~m}$ over the shallow shelf and $\sim 1 \mathrm{~km}$ seaward of the shelfbreak. Water column velocity and relative acoustic backscatter were measured using an RD Instruments 300 kHz broad-band Acoustic Doppler Current Profiler (ADCP) with bottom tracking mounted on a BioSonics acoustic sled that was towed at $\sim 1 \mathrm{~m}$ depth (Table 1). The ADCP malfunctioned during the 2005 survey, so few data were collected. Relative backscatter was calculated according to the method of Deines (1999).

Water column parameters such as temperature were plotted as a function of along-track latitude and depth when the boat reached the offshore end of each transect. Locations of fronts and high chlorophyll fluorescence features noted in the plots were targeted for discrete sampling on the inbound 
182 • C.J. ASHJIAN et al.

TABLE 1. Summary of parameters measured during the oceanographic fieldwork. Parameters are organized by the instrument or equipment used. Depths sampled are also noted.

\begin{tabular}{lll}
\hline \hline \multicolumn{1}{c|}{ Instrument/Equipment } & \multicolumn{1}{c}{ Parameters Measured } & \multicolumn{1}{c}{ Depth Range } \\
\hline Acrobat & $\begin{array}{l}\text { Temperature, salinity, pressure (depth), chlorophyll } \\
\text { a fluorescence, colored dissolved organic material, } \\
\text { optical backscatter }\end{array}$ & $\begin{array}{l}\text { Near-surface (1 m) to near bottom or to } 60 \mathrm{~m} \\
\text { maximum depth }\end{array}$ \\
Acoustic Doppler Current Profiler (ADCP) & $\begin{array}{l}\text { Water column velocity and relative acoustic } \\
\text { backscatter }\end{array}$ & $\bullet$ Near surface to $\sim 150 \mathrm{~m}$ maximum depth \\
Sea-Bird CTD, Fluorometer, Rosette & $\begin{array}{l}\text { Temperature, salinity, pressure, chlorophyll } a \\
\text { fluorescence } \\
\text { Water collected for chlorophyll a, nutrients, } \\
\text { photosynthetic picoplankton abundance }\end{array}$ & $\bullet$ Surface to near-bottom, no maximum depth $40 \mathrm{~m}$ \\
\hline \hline
\end{tabular}

portion of the transect using a CTD system and plankton nets. A Sea-Bird 19+ CTD equipped with a Wet-Labs WetStar fluorometer was used to measure temperature, salinity, and fluorescence at depths below the Acrobat profiling depths (Table 1). A SeaBird autofire rosette was used to collect water for analyses of chlorophyll $a$, nutrient concentrations, and photosynthetic picoplankton abundances. The rosette system frequently failed to fire, so water also was collected using Niskin bottles deployed on a hand line. Water was collected at $1 \mathrm{~m}, 10 \mathrm{~m}$, and $40 \mathrm{~m}$ depths in 2005 , but usually only at $1 \mathrm{~m}$ and $10 \mathrm{~m}$ depths in 2006. Plankton samples were collected at selected locations using a plankton net (60 $\mathrm{cm}$ diameter, 5:1 length-to-width ratio), equipped with $150 \mu \mathrm{m}$ mesh, a flow meter, and a time-depth recorder to determine actual sampling depth (Table 1).

Chlorophyll $a$ concentrations were analyzed just after water collection. The filters were extracted in $6 \mathrm{ml}$ of $90 \%$ acetone in $13 \times 100 \mathrm{~mm}$ glass culture tubes at $-20^{\circ} \mathrm{C}$ for 18 to 24 hours. At the end of the extraction period, the filter was carefully removed from each tube, and the chlorophyll $a$ concentration determined using a calibrated Turner Designs fluorometer. A solid chlorophyll $a$ standard was used to check for fluorometer drift at the beginning of each reading of chlorophyll $a$ samples. Extracted chlorophyll values were used to ground-truth the chlorophyll fluorescence sensors on the Acrobat and the CTD.

Nutrient samples were frozen just after collection. The nutrient analyses were performed using a hybrid Technicon AutoAnalyzer II ${ }^{\mathrm{TM}}$ and Alpkem RFA300 ${ }^{\mathrm{TM}}$ system, following protocols modified from Gordon et al. (1995). Standard curves with four different concentrations were run daily at the beginning and end of each run. Fresh standards were made prior to each run by diluting a primary standard with low-nutrient surface seawater. Triplicate de-ionized water blanks were analyzed at the beginning and end of each run to correct for any baseline shifts. In this protocol, the coefficients of variation for duplicates are typically less than $1 \%$ at low nutrient concentrations (Fleischbein et al., 1999), while at high nutrient concentrations, coefficients of variation are $2-3 \%$ for nitrate and silicate (Corwith and Wheeler, 2002). Water samples for measuring the abundance of photosynthetic picoplankton smaller than $5 \mu \mathrm{m}$ by flow cytometry were collected and then frozen at $-80^{\circ} \mathrm{C}$. In the laboratory, samples were thawed and kept on ice in a dark container until subsamples of $500 \mu \mathrm{l}$ were enumerated on a Becton-Dickinson FACSCalibur ${ }^{\mathrm{TM}}$ flow cytometer with a $488 \mathrm{~nm}$ laser (Sherr et al., 2005). Populations of coccoid cyanobacteria and of photosynthetic eukaryotes were distinguished by differences in side light scatter (SSC) and by fluorescence in orange (cyanobacteria) and in red (eukaryotic phytoplankton) wavelengths. Mesozooplankton samples were collected using oblique tows of a $0.6 \mathrm{~m}$ diameter ring net equipped with $150 \mu \mathrm{m}$ mesh, a flow meter, and a timedepth recorder. Because days are very long in August and September at this latitude, most samples were collected during daylight hours. Daylight collection, and the use of a ring net, likely resulted in underestimating euphausiid absolute abundances. However, relative abundances should be consistent throughout the two years of sampling.

Usually, both the inbound and outbound legs of each transect were sampled on a given sampling "day" (some days extended to $\sim 20$ hours in length). In 2005 , the transect lines were sampled over a period of 21 days. However, in 2006 a synoptic survey of Lines $1-5$, sampled from west to east, was conducted over a period of 2.5 days, using the Acrobat towed vehicle and the towed ADCP. Also in 2006, Transect Line 4 was sampled on three different dates, permitting description of the variability on time scales of days and weeks.

\section{Aerial Surveys}

In 2005 and 2006, whale distributions were documented by aerial surveys conducted along the oceanographic sampling transect lines. Surveys were flown at over $1000 \mathrm{~m}$ altitude in a high-wing aircraft equipped with bubble windows that provided experienced observers a $90^{\circ}$ viewing range from the horizon to the transect line. The number and locations of all marine mammals seen were logged on an onboard computer. Subsequently, bowhead whale distribution was mapped relative to bathymetry and integrated with stomach content and whaling data, as described in Moore et al. (2010). 


\section{Traditional Knowledge Interviews}

Traditional knowledge interviews with members of whaling crews were conducted in Barrow in February, March, April, and December of 2006. A list of active whalers from the North Slope Borough Department of Wildlife Management was used to identify knowledgeable bowhead whale hunters; those whalers subsequently were asked for the names of other active and knowledgeable bowhead whale hunters. We interviewed a total of 41 Iñupiat whale hunters, all of whom had been captains, co-captains, or crewmembers on fall Barrow whaling crews. Twenty-six of the whalers were captains or co-captains, and the remaining 15 were crew members. Partial interviews were conducted with an additional 27 Barrow hunters, who provided mapped information, bringing the total number of interviews with Barrow residents to 68. An interview guide was used during interviews. Interview topics were designed to complement the research being conducted by the oceanographers. A whaler's set of knowledge develops over time through repeated observation and from information passed on by knowledgeable elders. Thus, researchers asked respondents to provide lifetime knowledge and observations. Interview topics included (1) factors affecting fall bowhead whale hunting decisions and success, (2) bowhead whale hunting locations, (3) areas of bowhead whale aggregation during fall months, (4) bowhead whale migratory patterns, (5) bowhead whale feeding grounds; (6) prey fields and windrows, and (7) winds and currents associated with the above topics.

Respondents read and signed an informed consent form before the interview began. Two researchers were present for each interview. One study team member conducted the interview and recorded geographic information on an acetate sheet positioned over a 1:250 000 U.S. Geological Survey (USGS) map. A second team member took detailed notes on the respondents' comments using a laptop computer. Study team members entered the features recorded on the acetate overlays and the associated notes into an Access database designed for the project. All geographic features were digitized using ArcGIS software. The Access database was linked to the GIS database so that the GIS staff could develop maps by querying specific feature information.

\section{Retrospective Analysis}

Since the fieldwork encompassed only two years, analyses of past environmental conditions, bowhead whale distribution, and whaling records were undertaken to put the results of the 2005 and 2006 field seasons into a broader temporal context. Annual data sets included wind records from Barrow (K. Taylor, pers. comm. 2007), bowhead whale distributions in September and October for the years 1984-2004 from the Bowhead Whale Aerial Survey Project (BWASP) (J. Clarke, pers. comm. 2009; http://www.mms. gov/alaska/ess/bwasp/xbwasp.htm), and whaling records (start/end dates of whaling season, whaling strike locations and dates) compiled for the period 1985-2004 by the
Alaska Eskimo Whaling Commission and the North Slope Borough Department of Wildlife Management.

\section{RESULTS}

\section{Oceanographic Sampling and Whale Distributions}

Three principal water masses were observed across the study region (Fig. 3). Cold, salty Winter Water (WW) originates in the Bering and Chukchi seas when seawater is cooled to near freezing during the previous winter. Cold, fresh Melt Water (MW) derives from melting sea ice. Pacific Water (PW) is characterized by relatively warm temperatures and intermediate salinities due to summertime warming of Bering/Chukchi-origin coastal waters. Considerable between-year and shorter-term variability in the physical and biological conditions on the shelf was observed in 2005 and 2006, as demonstrated in the water masses present (Fig. 3) and in sections from across transect line 4 (Fig. 4). Interannual variability was driven by large-scale atmospheric and ocean circulation patterns that in turn influenced ice conditions and water mass distributions. During 2005, virtually no sea ice was present in the region, while in 2006 ice cover and MW were far more extensive and varied markedly with wind speed and direction. By contrast, much more PW was present in 2005 than in 2006. Temperatures and salinities were higher and fluorescence (chlorophyll) was lower in 2005 than in 2006. The highest temperature measured was $\sim 8^{\circ} \mathrm{C}$ in 2005 but only $\sim 4^{\circ} \mathrm{C}$ in 2006 (both in Barrow Canyon). The water column was highly stratified in 2006, particularly on 22 August, with very fresh water in the upper water column from sea ice melt associated with the extensive sea-ice cover.

Shorter-term variability was associated with changes in wind speed and direction, as demonstrated by the notable changes in physical and biological distributions on the time scale of days during 2006 (Figs. 4 and 5). Northeasterly winds blowing prior to and during the sampling on 22 August promoted upwelling in Barrow Canyon (note domed isotherms and isohalines in the upper $20 \mathrm{~m}$ centered near $71.60^{\circ}-71.65^{\circ} \mathrm{N}$ ) and associated higher levels of chlorophyll fluorescence. In contrast, sampling on 29 August occurred during and after weak winds. Stratification was much reduced because the lesser quantity of sea ice melt water allowed dense, saltier water to intrude onto the shallow shelf. The reduced stratification probably also contributed to low chlorophyll concentrations along the transect.

Coupling between water masses and biological (e.g., plankton abundance and type) and chemical (nutrient) characteristics was observed in both years. The most striking pattern was the absence of coccoid cyanobacteria in any of the water column samples collected in 2006 (Fig. 6). Although water samples were collected only in the upper $10 \mathrm{~m}$ in 2006, comparison of the temperature-salinityplankton diagrams from the two years reveals that coccoid cyanobacteria were present in most water masses in 

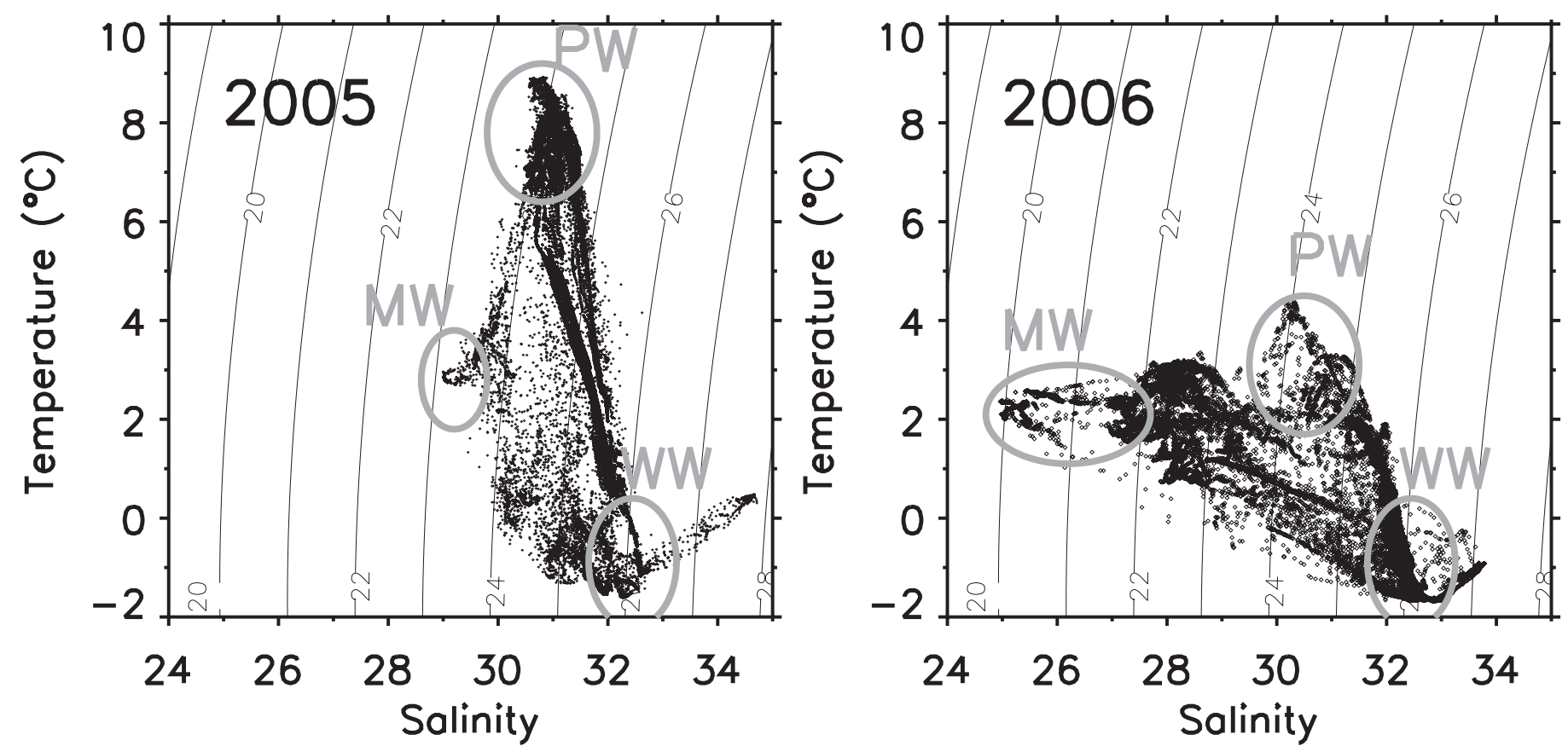

FIG. 3. Temperature-salinity diagrams from transects across Barrow Canyon in 2005 and 2006. Letters indicate dominant water masses: Pacific Water (PW), Melt Water (MW), and Winter Water (WW). Similar water masses were found across all transects. Lines of constant sigma-t (density) also are shown.
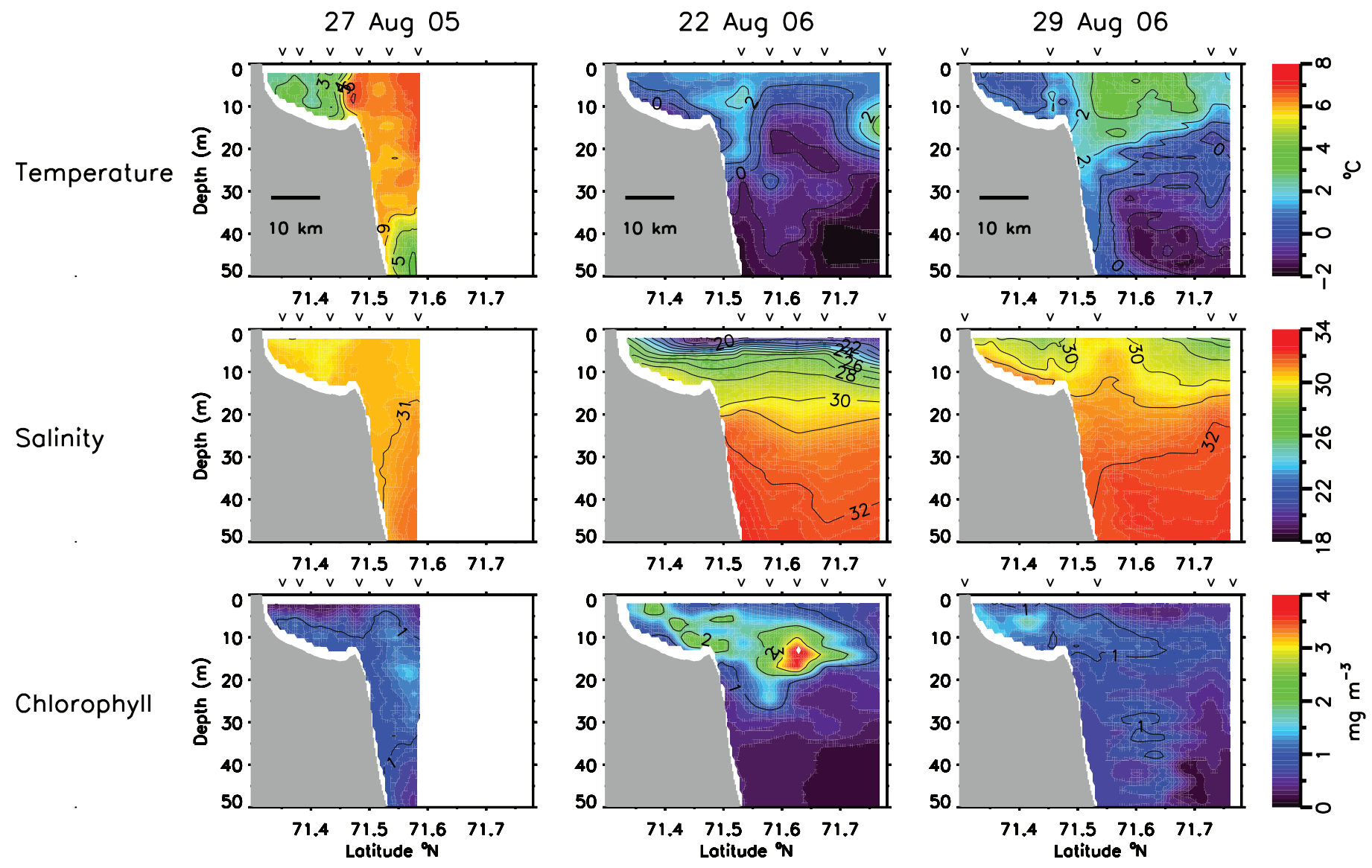

FIG. 4. Hydrographic and chlorophyll fluorescence sections taken along Transect 4 (Fig. 2) in 2005 (27 August) and 2006 (22 and 29 August). Each panel combines continuous data from the towed Acrobat with CTD data from sampling at discrete locations. Wedge symbols along the top axis show latitude of each CTD cast. 

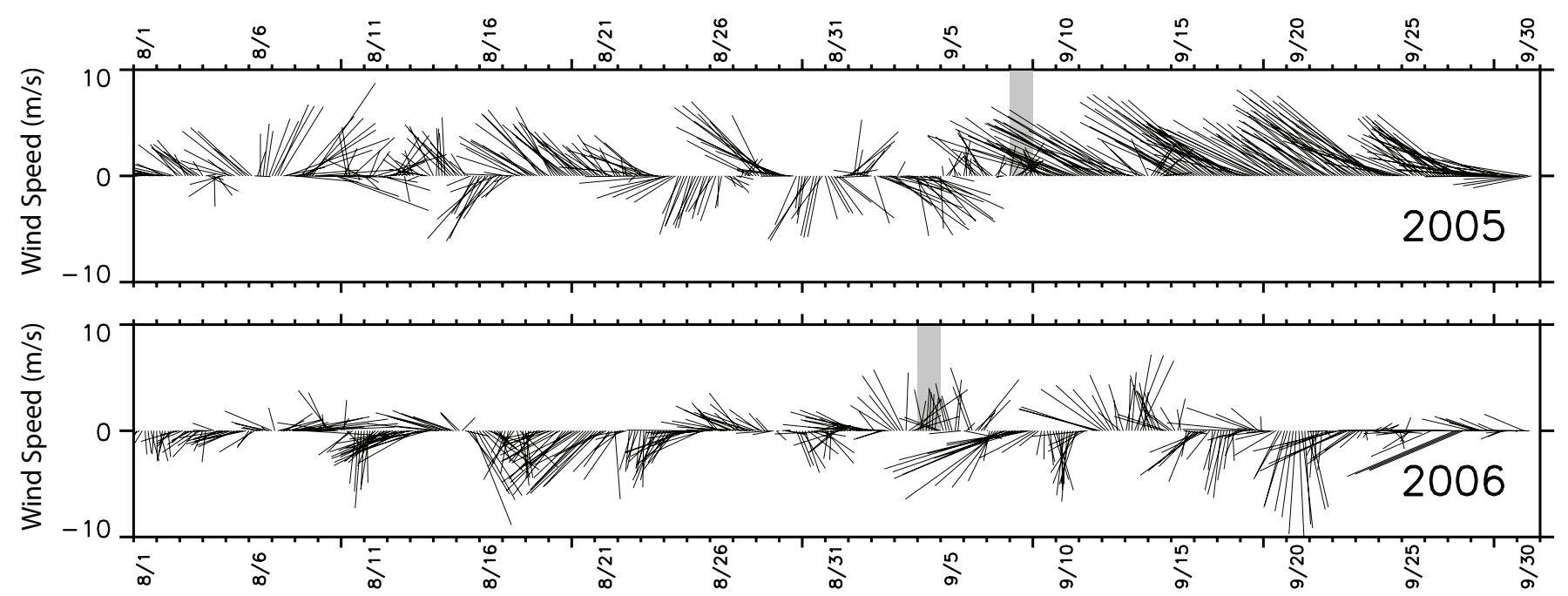

Date

FIG. 5. Wind vectors recorded at Barrow, Alaska, during the field sampling in 2005 and 2006. For wind direction, north is up. Shaded regions indicate dates on which whales were first sighted for each year.

\section{Coccoid Cyanobacteria $\left(10^{3} \mathrm{ml}^{-1}\right) \quad$ Diatoms $\left(10^{3} \mathrm{ml}^{-1}\right)$}
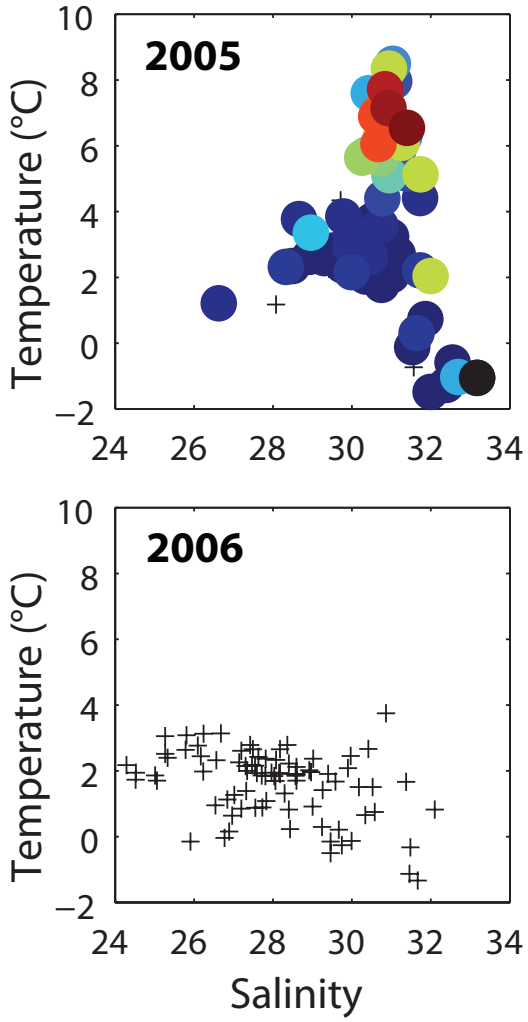
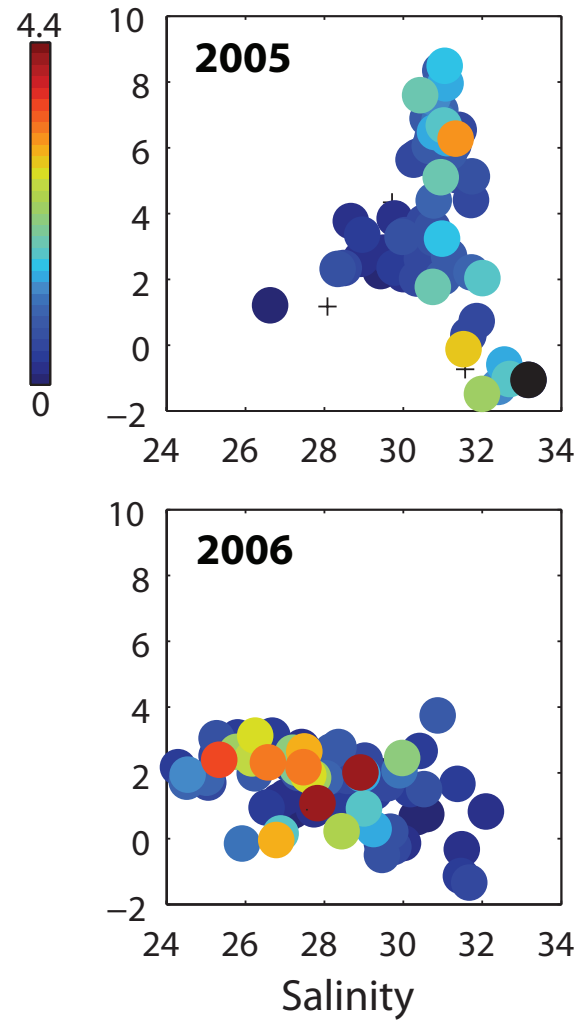

Nitrate \& Nitrite $\left(\mu\right.$ moles $\left.\left.\right|^{-1}\right)$
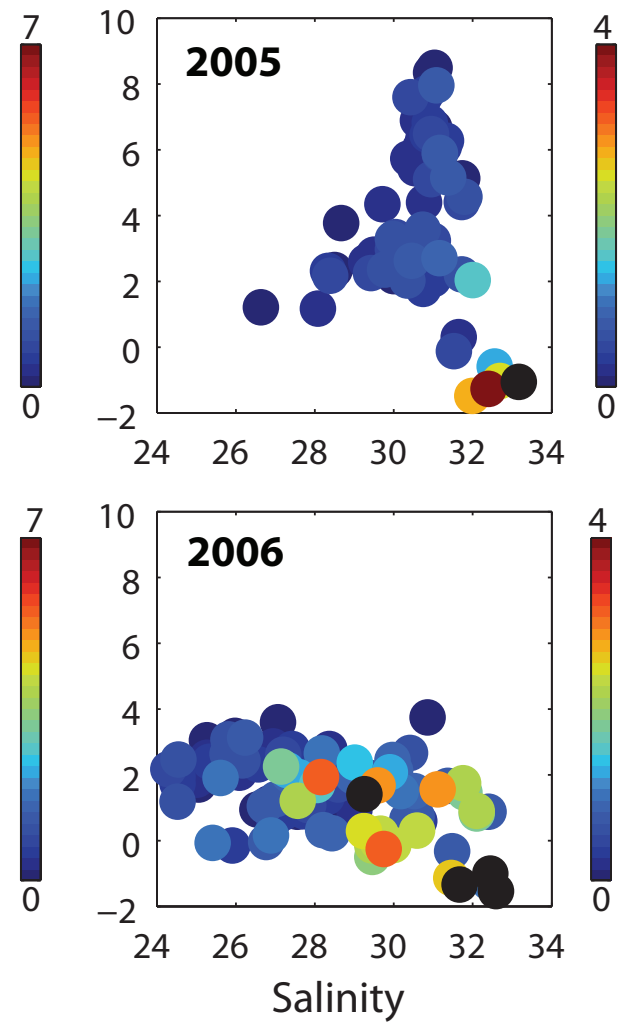

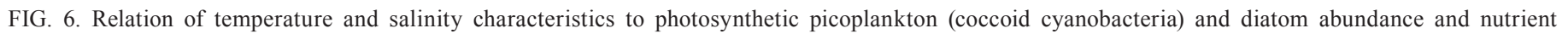

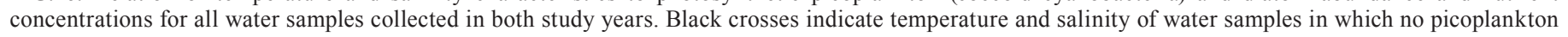
were observed. Black dots on color plots indicate abundances or concentrations that exceeded the color scale.

2005, not just the deep types, so that the absence of coccoid cyanobacteria in 2006 cannot be ascribed simply to sampling differences (note that very little PW was sampled during the water collections in 2006). Coccoid cyanobacteria were most abundant in PW in 2005. These organisms may be a tracer of PW in the Western Arctic. Diatoms were most abundant in PW and in the deeper (10-40 m) WW, with very low abundances in the limited MW in 2005 but much 

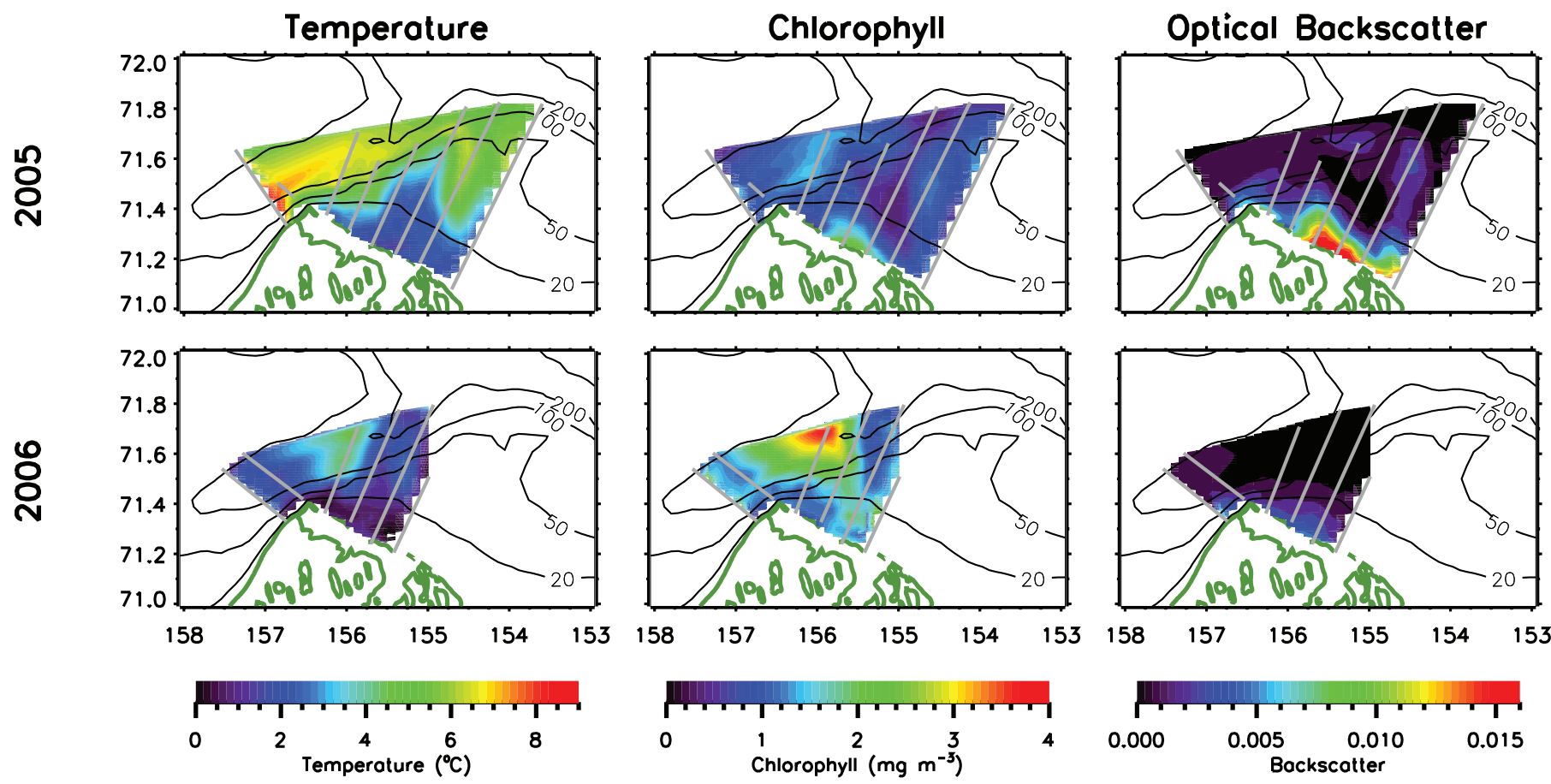

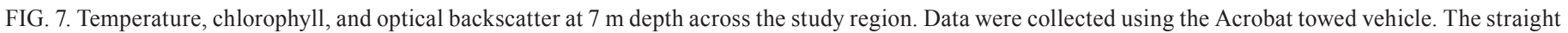
white lines plotted over the contours are the track lines. Bathymetry lines show the 20, 50, 100, and $200 \mathrm{~m}$ isobaths.

higher abundances in MW in 2006. The latter abundances may have been associated with the high stratification in regions with melt water. Nutrient concentrations, represented here by nitrate and nitrite, were highest in the deeper WW for both years, likely as a result of regeneration over the winter, and also were elevated in the MW in 2006. Very low nitrite and nitrate concentrations were seen in PW.

Considerable complexity was observed in the spatial distribution of physical and biological properties (Fig. 7). Although the time scales over which the surveys were conducted differed between the two years ( 3 weeks in 2005 vs. 4.0 days in 2006), some similarities in general distributions were observed. Warmer water was observed over Barrow Canyon in both years, with colder water on the shelf. Water temperature in Barrow Canyon was much higher in 2005 than in 2006, reflecting the presence of a more distinct PW mass in the region during 2005. Chlorophyll concentrations were greater in 2006, especially in Barrow Canyon, likely because of increased stratification due to ice melt and elevated nutrients in the upper water column (Fig. 6) in that year. Elevated chlorophyll was also observed near shore in both years in association with outlets from Elson Lagoon. Optical backscatter in 2005 was extremely high offshore of the Elson Lagoon barrier islands because of the elevated sediment load in the water there.

Despite the differences in ocean conditions, bowhead whales arrived suddenly in early September of both years and were observed at locations that likely were related to availability of their prey (Fig. 8; Moore et al., 2010). On 8 September 2005, over 100 whales were observed near the sediment plume (Fig. 7) along the barrier islands of Elson Lagoon. Large (juvenile and adult) euphausiids were found inside of Elson Lagoon, with high concentrations at the western end, and also in moderate concentrations just outside the lagoon, in the region where whales had been feeding (Fig. 9). A smaller aggregation of whales was also seen in Barrow Canyon. Winds were from the southeast on 5-7 September (upwelling-favorable for Beaufort Sea shelf) and from the southwest on the day of the whale sightings (Fig. 5). Large euphausiids were also observed by the oceanographic field team on 13 September 2005 during southeasterly winds. They were washed up along the beaches inside the western end of the lagoon, which is consistent with Barrow whale hunters' observations of krill on the southwest shore of Elson Lagoon. In 2006, whales were first sighted on 4 September, on the Beaufort Sea shelf near the $20 \mathrm{~m}$ isobath north of the Elson Lagoon barrier islands and just south of where the ice edge was located on that day (Fig. 8). Observations during aerial surveys and from local boats indicate that whales remained on the shelf and canyon slope north and northeast of Point Barrow for at least three days. These observations again were made during a period of winds from the southern quadrant that followed an extended period of upwelling-favorable winds from the southeast. In contrast to the late August conditions, high relative acoustic backscatter throughout the water column and elevated large euphausiid concentrations were present on the shelf immediately after the arrival of the whales and these wind events (Figs. 9 and 10). Bowhead whales were observed feeding in the region, where large euphausiids were abundant, on both 4 and 5 September 2006, and net sampling near the whales confirmed the presence of juvenile and adult euphausiids at those locations (Fig. 9d). Large euphausiids and high backscatter extended eastward to at 


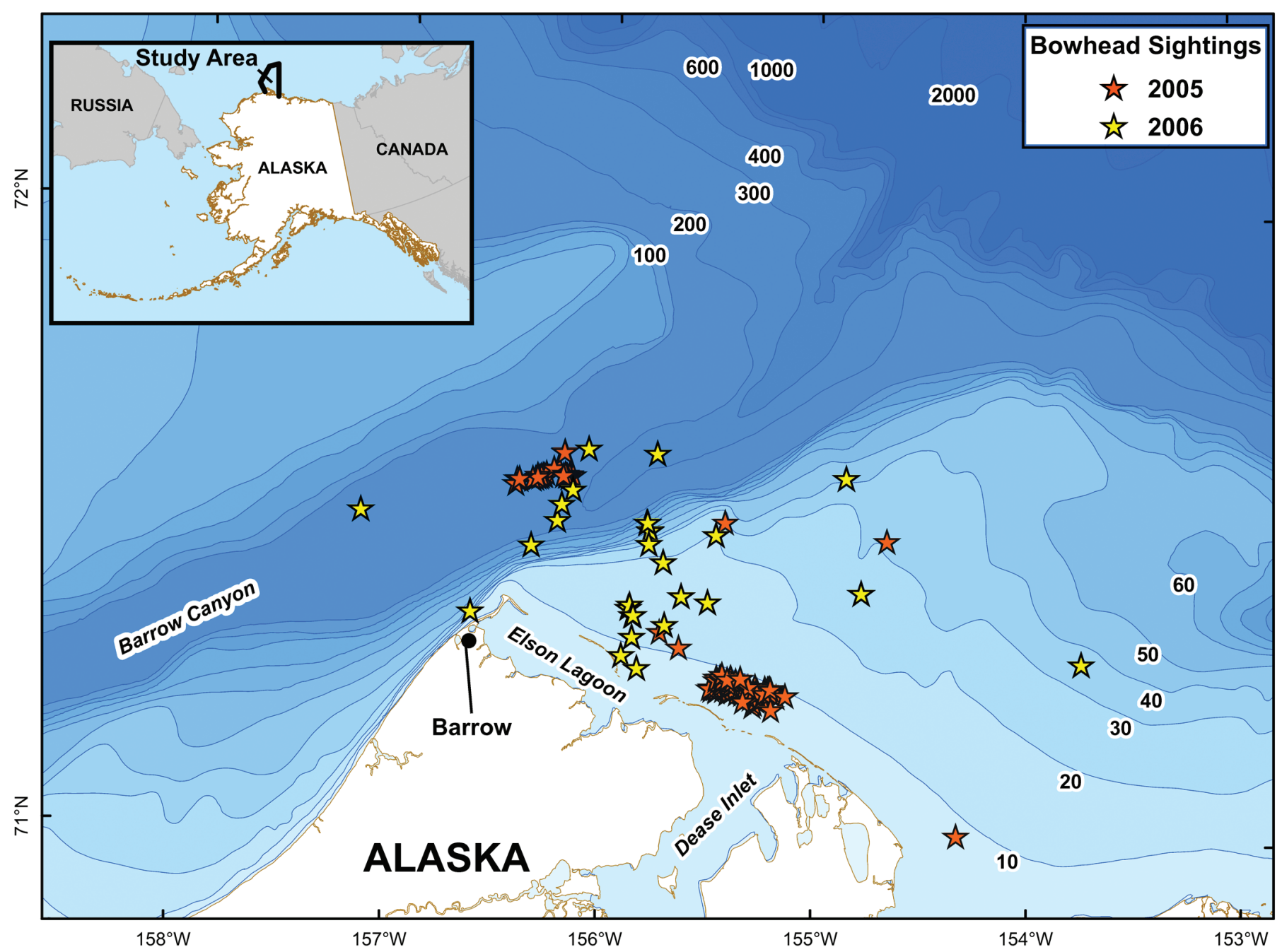

FIG. 8. Distributions of bowhead whales from aircraft surveys in 2005 (red stars) and 2006 (yellow stars).

least $15 \mathrm{~km}$ east of Point Barrow. Before the arrival of the whales and the upwelling winds, large euphausiids were scarce or absent at most locations on the shelf although the much smaller furcilia were present at many locations sampled when whales were not present.

\section{Retrospective Analysis and Traditional Knowledge Interviews}

A comparison of wind direction and number of whales in each sighting near Barrow during BWASP aerial surveys (September-October, 1984-2004) showed that the mean size of whale groups was significantly larger on days when winds were from the south compared to any other direction except the north (ANOVA, $p<0.001$; least significant difference post-hoc test, $\alpha=0.05$ ). Mean whale group size on north-wind days did not differ significantly compared to days with winds from another direction (Fig. 11a). Analysis of the wind direction averaged over the two to three days preceding each observation indicated that mean size of whale groups was significantly larger following periods of winds from the southeast (ANOVA, $p<0.001$; least significant difference post-hoc test, $\alpha=0.05$ ), which favored upwelling of euphausiids onto the Beaufort Sea shelf from along the shelf-break. These wind-whale associations were consistent with the wind directions observed at the times of arrival of the whales during the field seasons of 2005 and 2006.

Whales were hunted successfully at Barrow every fall from 1985 to 2004, except in 1986 (Table 2). The hunting season typically began in late September, with the start date agreed upon by the local whalers, although occasionally (e.g., in 1992 and 1995) whales were landed as early as the end of August or the first week of September. The mean length of the fall hunt is $19 \pm 15$ days (mean $\pm \mathrm{SD}, \mathrm{n}=19$ years), but there is significant variation between years (season length ranges from a few days up to over five weeks). On average, a whale was landed every two days during the fall hunting season from 1985 to 2004. Therefore, for the past several decades whales have been reliably present, and hunted, at Barrow every fall. In most years, whales were present near Barrow for at least two weeks $(n=14$ years out of 20); since 1992, whales have been present for six weeks or longer. Despite the recurrent and predictable availability 

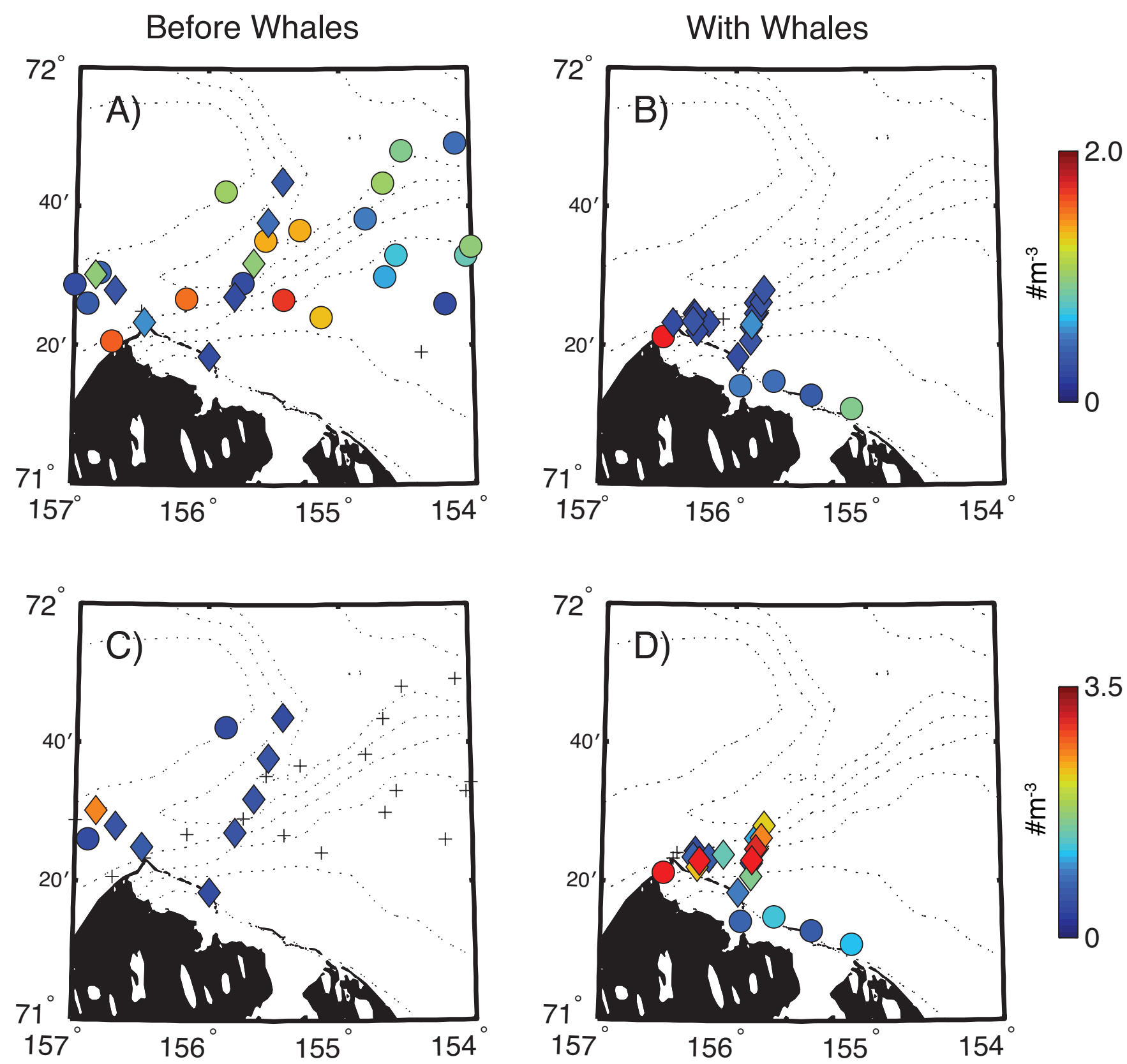

FIG. 9. Distributions of euphausiid furcilia (A, B) and juveniles/adults (C, D) before and after the arrival of bowhead whales at Barrow. Filled circles indicate locations sampled in 2005; diamonds indicate locations sampled in 2006; color indicates concentration at each location. Small black cross symbols indicate sampling locations where no euphausiids were collected.

of bowheads each fall, the total number of bowhead whales landed during the fall hunting season varies considerably from year to year (Table 2). The low fall harvest totals before 1992 were primarily due to an annual quota imposed by the International Whaling Commission in 1979, but even since that quota was significantly increased in 1992, the fall harvest has been variable and bimodal, with one mode centered on $\sim$ five whales per year and the other at $\sim 20$ whales per year (Fig. 12). After 1992, in those years with a low fall total, the spring hunt had supplied a good number of whales. Conversely the four years of high fall harvest totals (with the one exception of 1997) were all years in which the spring hunt had been relatively unsuccessful, and the community was therefore still in need of whale meat. The flexibility to hunt in both seasons is therefore an important aspect of the resilience of the subsistence system.

Barrow whale hunters indicated in interviews that bowhead whales are often seen along the barrier islands bounding Elson Lagoon and on the Beaufort Sea shelf to the N and NE of Point Barrow, along the eastern edge of Barrow Canyon (Fig. 13). Most bowhead whale strikes during hunting $(146 / 166$, or $88 \%)$ coincide spatially with these locations, although some occurred over Barrow Canyon to the west. Barrow whale hunters reported observing bowhead 


\section{Before Whales}

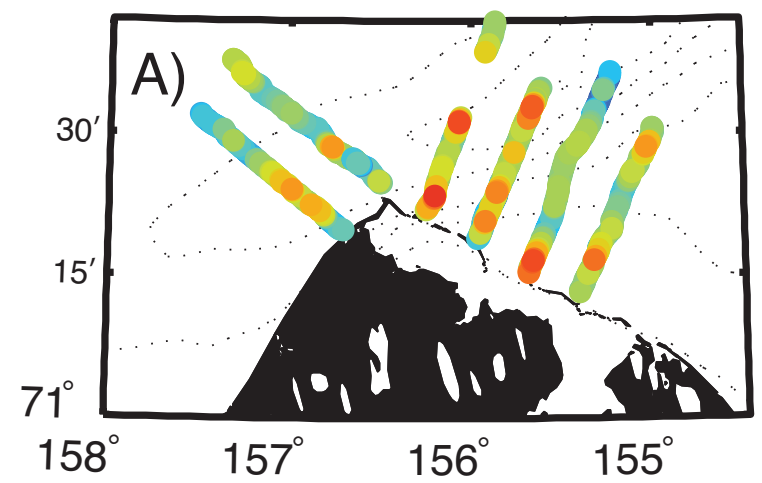

\section{With Whales}

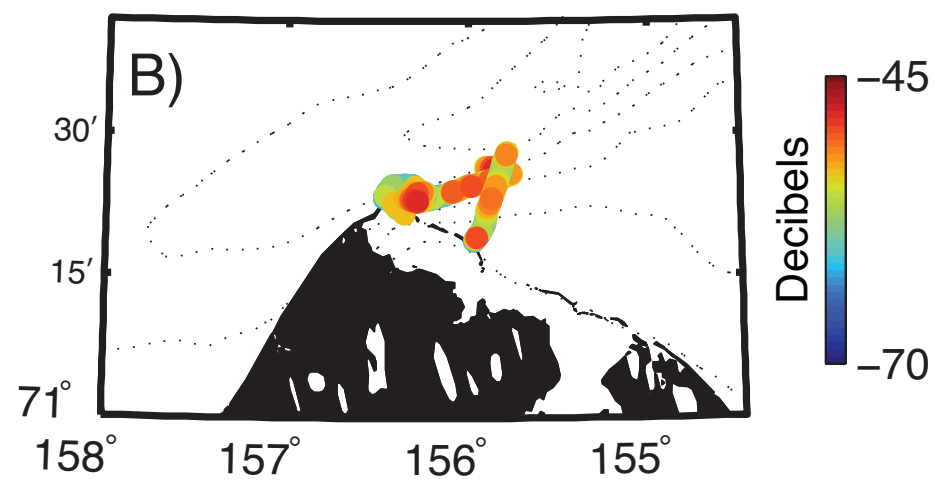

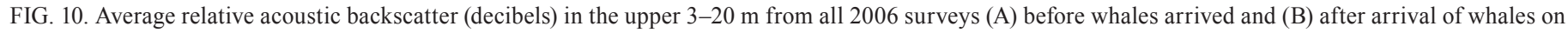
the shelf.
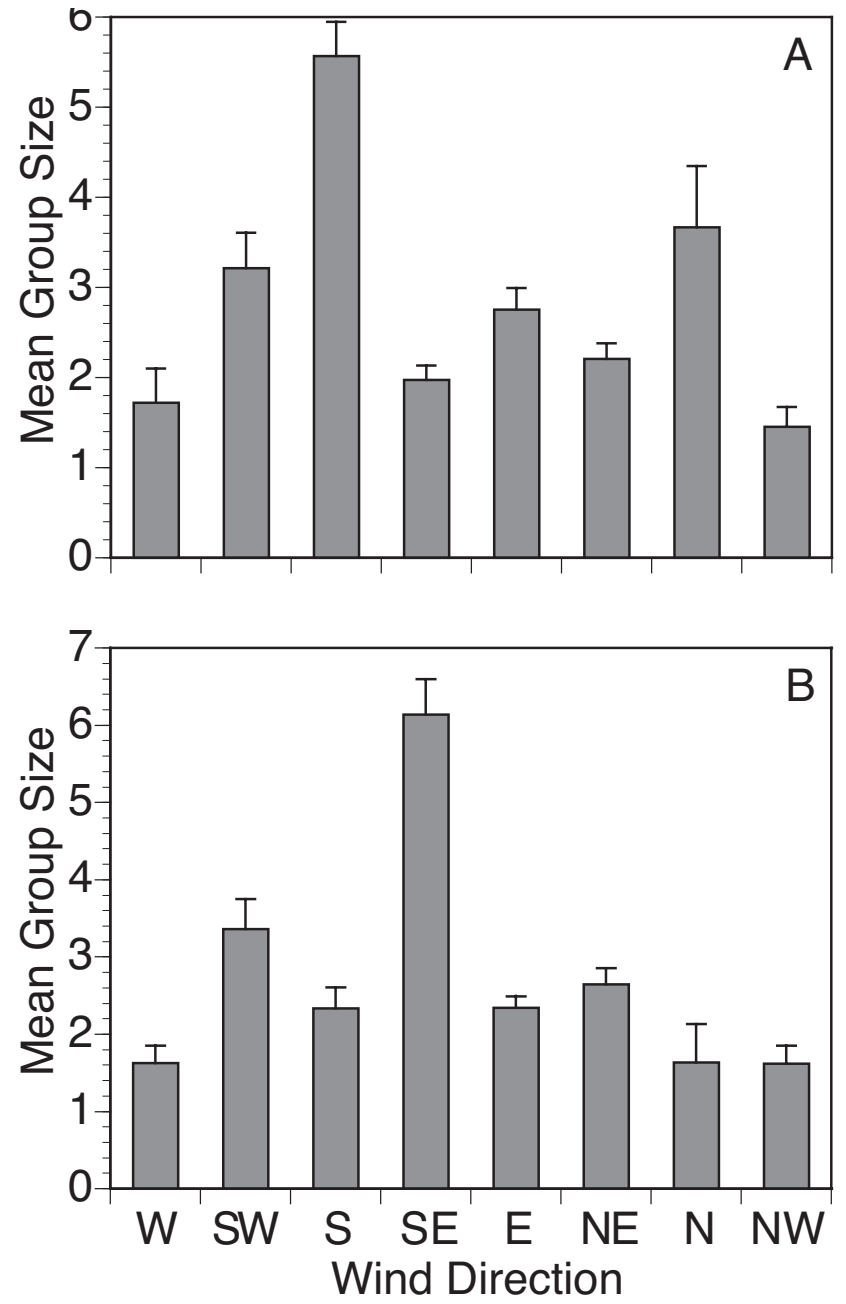

FIG. 11. Whale group size as a function of wind direction A) on the day of each BWASP observation and B) averaged over 2-3 days prior to each BWASP observation. Standard errors are shown above bars.

whales milling around or feeding in front of the barrier islands. Fronts $\mathrm{N}$ and NE of Point Barrow and outside the barrier islands, described by the whale hunters as areas where murky and clear water or two different currents meet, must be rich with feed for bowhead whales since feeding bowhead whales are also observed at those locations. Few whale hunters reported seeing bowhead whales inside Elson Lagoon, and none identified Elson Lagoon itself as a feeding ground.

\section{DISCUSSION}

These two years of oceanographic and whale distribution data, together with the retrospective analysis and traditional knowledge, demonstrate that the formation of a bowhead whale feeding area near Barrow (1) is recurrent, (2) results from a particular combination of environmental factors that act synergistically to promote whale prey aggregations, (3) is persistently used by the whales despite the major differences in the oceanographic environment observed during our two years of intensive field study, and (4) provides important and reliable fall bowhead hunting opportunities for the Iñupiat residents of Barrow.

Local availability of bowhead whale prey, particularly euphausiids, on the shelf near Barrow is tied to wind-driven circulation. Although they did not provide specific information about the relationship between wind and the availability of bowhead whale prey, Barrow hunters agreed that the locations of windrows and prey fields are directly related to wind direction. At least two mechanisms appear to be operating in concert. The first occurs under upwelling winds, when euphausiids are advected onto the Beaufort Sea shelf from the Beaufort Sea slope (during winds from the $\mathrm{E}$ or $\mathrm{SE}$ ) or perhaps from Barrow Canyon (during winds from the N or NE) and are distributed across the Beaufort Sea shelf (Fig. 14; Okkonen et al., 2009). When winds are weak or from the S or SW, the Alaska Coastal Current runs tightly along the eastern edge of Barrow Canyon, and eastward intrusion of warm PW from Barrow Canyon onto the western Beaufort Sea shelf inhibits the local off-shelf movement of water and euphausiids. Since the prevailing current on the Beaufort Sea shelf is to the northwest, euphausiids are further concentrated in the triangular region bounded 
TABLE 2. Interannual variability in fall whale harvest, reported start of whale presence at Barrow from hunting strike data and BWASP data $\left(154-157^{\circ} \mathrm{W}\right)$, and number of days each year from 1 September to 31 October with wind conditions suitable for hunting. The length of the fall hunting season is based on the dates of the first and last reported whale strikes and may therefore be a slight underestimate. The actual date on which hunting begins in a given year is sometimes a few days earlier than the first whale strike.

\begin{tabular}{|c|c|c|c|c|c|c|}
\hline Year & $\begin{array}{l}\text { Spring hunt } \\
\text { (\# whales) }\end{array}$ & $\begin{array}{l}\text { Fall hunt } \\
\text { (\# whales) }\end{array}$ & $\begin{array}{c}\text { First fall } \\
\text { whale landed }\end{array}$ & $\begin{array}{c}\text { First fall } \\
\text { BWASP sighting }\end{array}$ & $\begin{array}{c}\text { Approximate length } \\
\text { of fall hunt (days) }\end{array}$ & $\begin{array}{l}\text { Days with wind } \\
<6 \mathrm{~m} / \mathrm{s} \text { (Sept-Oct) }\end{array}$ \\
\hline 1985 & 4 & 1 & $10 / 13$ & $10 / 1$ & 1 & 34 \\
\hline 1986 & 7 & - & - & $10 / 12$ & - & 32 \\
\hline 1987 & 5 & 2 & $10 / 22$ & $9 / 27$ & 8 & 24 \\
\hline 1988 & 8 & 3 & $9 / 15$ & $10 / 12$ & 3 & 33 \\
\hline 1989 & 3 & 7 & $10 / 2$ & $9 / 30$ & 27 & 25 \\
\hline 1990 & 6 & 5 & $10 / 1$ & $10 / 9$ & 22 & 21 \\
\hline 1991 & 8 & 4 & $9 / 16$ & $9 / 29$ & 19 & 31 \\
\hline 1992 & 2 & 20 & $8 / 31$ & $10 / 15$ & 44 & 33 \\
\hline 1993 & 16 & 7 & $10 / 5$ & $9 / 12$ & 16 & 15 \\
\hline 1994 & 15 & 1 & $10 / 1$ & $10 / 8$ & 1 & 39 \\
\hline 1995 & 10 & 11 & $9 / 4$ & $9 / 18$ & 45 & 28 \\
\hline 1996 & 5 & 19 & $9 / 10$ & $9 / 12$ & 17 & 37 \\
\hline 1997 & 9 & 21 & $9 / 11$ & $9 / 21$ & 41 & 38 \\
\hline 1998 & 9 & 16 & $9 / 19$ & $9 / 13$ & 19 & 37 \\
\hline 1999 & 18 & 6 & $10 / 9$ & $9 / 24$ & 5 & 39 \\
\hline 2000 & 5 & 13 & $9 / 25$ & $9 / 2$ & 14 & 35 \\
\hline 2001 & 21 & 7 & $10 / 7$ & - & 3 & 36 \\
\hline 2002 & 3 & 19 & $9 / 30$ & $8 / 25$ & 26 & 32 \\
\hline 2003 & 10 & 6 & $10 / 8$ & $9 / 16$ & 7 & 31 \\
\hline 2004 & 7 & 15 & $9 / 18$ & $9 / 5$ & 37 & 32 \\
\hline
\end{tabular}

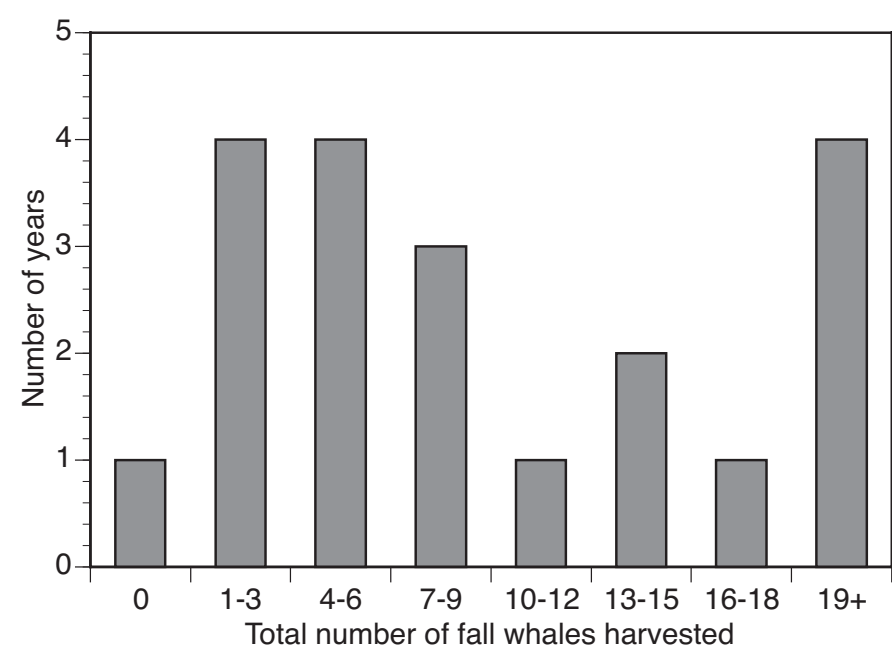

FIG. 12. Frequency histogram of total fall whale harvest at Barrow, Alaska, 1979-2001.

to the west by Barrow Canyon, to the $\mathrm{N}$ and $\mathrm{E}$ by the shelf break front, and to the south by barrier islands of Elson Lagoon. Retrospective analysis (Fig. 11) demonstrated that large groups of whales tend to be observed in this triangular region when wind conditions promote aggregations of euphausiids. This favorable feeding environment for bowhead whales, in turn, affords a favorable hunting environment for local whalers (Fig. 13).

The second mechanism involves aggregation of euphausiids in Elson Lagoon. Euphausiids that have been transported onto the shelf in response to upwelling-favorable (southeasterly-easterly) winds are carried into the shallow Elson Lagoon system by non-tidal currents associated with winds from the east. This transport is demonstrated by the presence of euphausiids in the lagoon following a

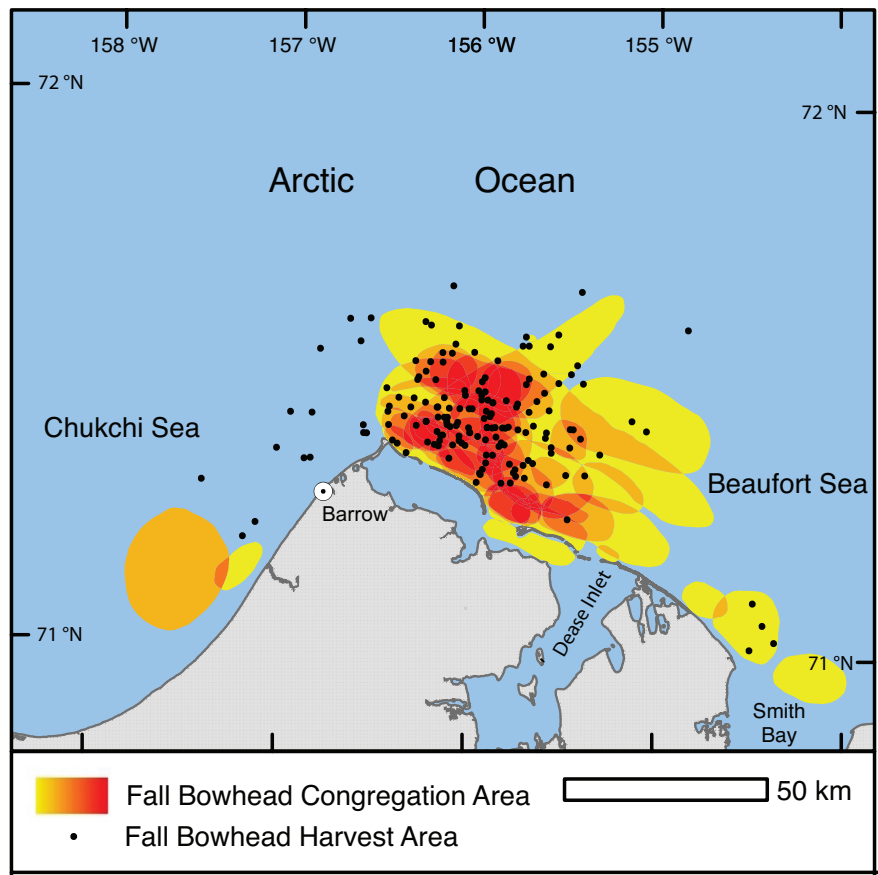

FIG. 13. Fall bowhead congregation areas (in respondents' lifetime up to 2006) and harvest locations (1988-2005). Color represents the number of overlapping polygons of whale congregation areas (yellow $=$ low, red $=$ high) reported by 35 respondents in interviews with 41 Barrow fall whalers. The 166 harvest locations shown are based on North Slope Borough Department of Wildlife Management and Alaska Eskimo Whaling Commission data. Locations are shown for landed whales with GPS coordinates or specific range and bearing (location data prior to 1988 are not specific and are therefore not displayed). Of the 166 harvest locations, 146 (88\%) fall within the reported whale congregation areas.

strong easterly wind (Figs. 5 and 9d) and the strong correlations between wind direction and currents from moorings deployed in Elson Lagoon inlets in August and September 2006 (Okkonen, 2008). Once the euphausiids are in the 

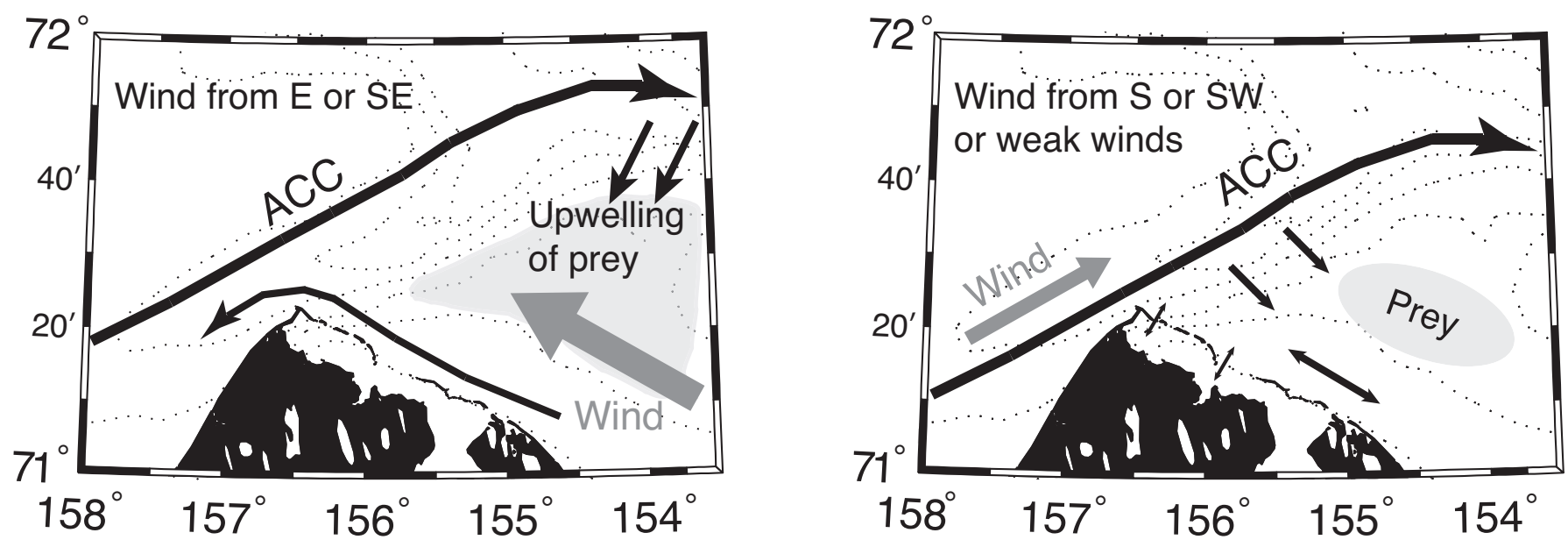

FIG. 14. Schematic diagram of the physical mechanisms that produce aggregations of euphausiids on the Beaufort Sea shelf to the NE of Point Barrow. Black arrows show currents; gray arrows show winds. ACC is the Alaska Coastal Current.

lagoon, wind-driven currents carry them downwind, effectively concentrating them at the windward end of the lagoon (Fig. 9d). Water, euphausiids, and sediment then flow out of the lagoon through the barrier island passages onto the nearshore Beaufort Sea shelf. (Note the high abundance of euphausiids at the western end of the lagoon in Fig. 9d when whales were present.) Whales were observed outside of Elson Lagoon in 2005 (Fig. 8), following a period of wind from the east, and whales frequently are observed outside of these passages by local whalers (Fig. 13). Together these observations suggest that Elson Lagoon functions as a euphausiid reservoir under certain wind conditions and that the water and euphausiids flowing out of the lagoon during those conditions provide a favorable feeding environment for the whales near the barrier islands. It is likely that euphausiids aggregate along the front between the sediment plume and the clearer shelf water where bowhead whales have been recurrently observed to feed.

On a larger scale, if euphausiids are expatriates from the northern Pacific and not endemic to the Chukchi and Beaufort seas, then euphausiid presence near Barrow is a function of their transport northward from the Pacific Ocean. This transport in turn should be significantly affected by interannual variability in the transport of Pacific Water, which is influenced by large-scale atmospheric conditions that drive mesoscale circulation. Physical modeling of the two phases of the Arctic Oscillation (AO) has demonstrated significant differences in the extent of Pacific Water penetration onto the Beaufort Sea shelf and and into the Beaufort Sea; Pacific Water can reach as far east as Kaktovik, Alaska, during the positive phase of the $\mathrm{AO}$, but does not move significantly past Barrow during the negative phase (e.g., Maslowski et al., 2001). Under either condition, Pacific Water, and hence euphausiids, should reach Barrow by fall each year. Modeling of euphausiid transport scenarios has demonstrated that euphausiids entering the Chukchi Sea through the Bering Strait can reach Barrow in a period as short as six months if entrained in the easternmost branch of northward circulation or in the Alaska Coastal Current (Berline et al., 2008). Hence, euphausiids can be a regularly occurring prey item for bowhead whales at Barrow, at least in autumn. Euphausiids frequently are the dominant prey of bowhead whales (e.g., Frost and Lowry, 1984; Lowry et al., 2004; Moore et al., 2010) and other marine mammals near Barrow for much of the year. However, both their relative rareness in the Western Arctic outside of the region near Barrow and the presence of a persistent, fairly direct transport mechanism between the Bering Sea and Barrow support the idea that euphausiids are not endemic to the region but rather are expatriates (and hence cannot reproduce and sustain a population).

To date, climate variability does not appear to have significantly affected the presence of a favorable feeding environment for the bowhead whale at Barrow. Although these inferences about the predictable annual presence of high prey concentrations (and consequent high probability of bowhead presence) come from only two years of detailed field observations, they are further supported by our analysis of more than two decades of whale harvest data (19792006) and up to 20 years of aerial survey data (1984-2004).

Fall whaling success depends on a suite of environmental and social factors. Environmental factors include availability of whales, weather suitable for safe hunting (e.g., wind speed; George et al., 2003), the presence of whales and their location relative to shore (distance, bearing) and in known places, local ice cover (Moore and Laidre, 2006), and air temperatures cool enough to prevent spoilage of meat during butchering. Social factors include local demand for subsistence meat; the number of whaling captains and crews active in a given season; community and institutional policy decisions, such as the determination of the start date of whaling by the local whaling captains' association and the whaling quota set by the International Whaling Commission; and local search-and-rescue capabilities.

Three factors explain much of the variability in the total fall harvest from 1980 to 2005. First, the total annual 
demand for meat, although relatively constant, can sometimes be substantially met by the spring hunt (as in 1993 or 1999, and in contrast to years like 1992 and 2002, when the spring harvest essentially failed because of adverse ice conditions). Second, in 1979, the International Whaling Commission instituted a quota restricting the number of allowable strikes. Although this quota has been raised in recent years as the population has increased, it considerably suppressed total harvest numbers from 1979 to the mid-1990s, when it was set too low to meet the community's need for whale meat. Third, local wind conditions must be suitable for hunting. Analysis of daily wind data from Barrow shows that $86 \%$ of fall whales were landed on days when the 24-hour daily speed was less than $6 \mathrm{~m} / \mathrm{s}$, and that no whales were ever landed when daily average wind speed exceeded $10 \mathrm{~m} / \mathrm{s}$. Since daily average wind speed in September and October was more than $6 \mathrm{~m} / \mathrm{s}$ for $48.6 \%$ of the time and more than $10 \mathrm{~m} / \mathrm{s}$ for $12.1 \%$ of the time, this quantitative wind speed analysis confirms local hunters' knowledge about the importance of safe wind conditions (George et al., 2003). A particularly windy fall may limit the number of days on which whales can be safely hunted. A relaxation of wind is necessary both for whaling safety and for the formation of whale prey aggregations.

Will Iñpiat whale hunting at Barrow continue to be successful? For the past two decades and at present, the window of opportunity for fall whaling at Barrow (from the third week in September to early or mid October) has been sufficiently long that enough days with good weather and suitably located whales have coincided, allowing Barrow hunters to achieve their annual quota. However, future weather conditions might worsen if wind patterns are altered by climate change. In addition, whale migration pathways could be altered in the future because of changes in whale prey availability (from oceanographic, sea-ice, or marine ecosystem changes) or because whales avoid the Barrow region in response to human activity (such as offshore oil drilling, increased ship traffic, or an oil spill downstream in the Chukchi Sea or locally on the Beaufort Sea shelf). Under any of these conditions, whaling could become more dangerous and difficult and might be less successful. During interviews, Barrow hunters reported having to travel farther from Barrow to harvest bowhead whales when barge activity deflected the whales from shore. Hunters stressed that whales should be harvested closer to the community so that the meat does not spoil during the tow back to shore. Alternatively, climate change could result in greater transport of Pacific Water, and euphausiids, to the Barrow region, thereby enhancing the feeding opportunities for bowhead whales near Barrow and potentially extending the period during which bowhead whales are present in the fall.

\section{SUMMARY}

Significant interannual and shorter-term variability was observed in oceanography, weather (wind), fall whale harvest success, and the dates and length of the bowhead harvest season. During the two years (2005 and 2006) of our intensive oceanographic fieldwork, interannual variability related to larger-scale climate affected water mass characteristics and associated biological and chemical properties. Shorter-term variability was driven by wind speed and direction, with dramatic impacts on the distribution and abundance of plankton, particularly bowhead whale prey (euphausiids). Despite these interannual differences in ocean conditions, bowhead whales reached Barrow during their fall migration in early September of both field years. Retrospective analyses showed that between 1985 and 2004, whales had reached Barrow as early as August 25. Transport of euphausiids from the Pacific Ocean to Barrow in the large-scale circulation, coupled with local wind forcing, provides at least two mechanisms by which euphausiids are concentrated on the western Beaufort Sea shelf near Barrow, resulting in a predictable and abundant food supply for the bowhead whales during their migration. Because the development of this feeding region and the arrival of the whales appear to persist despite ongoing climate variability, the fall whale harvest by the Iñupiat community at Barrow should be relatively resilient to climate change. The whale harvest at Barrow could, however, be particularly vulnerable to anthropogenic activities such as ship traffic, oil development, or an oil spill.

\section{ACKNOWLEDGEMENTS}

Many people contributed to the success of this project. Captain Bill Kopplin and co-captains Ned Manning and Mike Johnson of the R/V Annika Marie were integral members of the project team. We particularly thank the local bowhead whale hunters who provided their time and knowledge during interviews. Philip Alatalo (Woods Hole Oceanographic Institution), Aaron Hartz (Oregon State University), and David Leach (University of Alaska Fairbanks) provided critical sampling, logistic, and analysis support for the oceanographic fieldwork. Daniel Torres (Woods Hole Oceanographic Institution) processed the 2006 ADCP data. Joe Jennings (Oregon State University) analyzed the nutrient samples. Elizabeth Sears, Stephanie Schively, and Iris Prophet of Stephen R. Braund \& Associates conducted interviews, prepared maps, and analyzed data from the interviews with the Barrow whalers. Ralph Aiken piloted the 2005 aerial surveys. Aerial surveys in 2006 were flown in collaboration with Charles Monnett of the Minerals Management Service. Logistic support at Barrow both before and during the project was provided by the Barrow Arctic Science Consortium (BASC); many thanks to Glenn Sheehan, Henry Gueco, Robert Bulger, Alice Drake, and all members of the BASC staff. Logistic support at Prudhoe Bay was provided through Veco Polar Services and coordinated by Marin Kuezinga. Access to West Dock in Prudhoe Bay was facilitated by Bill Streever and Wilson Cullor of British Petroleum. Two high school teachers, Jeff Manker and Kirk Beckendorf, participated in the fieldwork with support of the NSF-sponsored ARMADA program at the University of Rhode Island. We thank the Barrow 
Whaling Captains Association, particularly Eugene Brower, the Alaska Eskimo Whaling Commission, the City of Barrow, and the North Slope Borough for their support of this project. Cyd Hanns, Robert Suydam, Harry Brower, and Taqlik Hepa of the North Slope Borough Department of Wildlife Management also contributed to the success of this project. We thank also Lloyd Lowry and an anonymous reviewer for their comments and suggestions that improved this manuscript. This work was supported by NSF Grants OPP-0436131 to C. Ashjian (S. Braund Subcontract), OPP0436110 to R. Campbell, OPP-0436127 to W. Maslowski, OPP0436009 to C. Nicolson and J. Kruse, OPP-043166 to S. Okkonen, and OPP-0435956 to Y. Spitz, E. Sherr, and B. Sherr.

\section{REFERENCES}

Aagaard, K., and Roach, A.T. 1990. Arctic ocean-shelf exchange: Measurements in Barrow Canyon. Journal of Geophysical Research 95:18163-18175.

Baumgartner, M.F., and Mate, B.R. 2003. Summertime foraging ecology of North Atlantic right whales. Marine Ecology Progress Series 264:123-135.

Baumgartner, M.F., Cole, T.V.N., Campbell, R.G., Teegarden, G.J., and Durbin, E.G. 2003. Associations between North Atlantic right whales and their prey, Calanus finmarchicus, over diel and tidal time scales. Marine Ecology Progress Series 264:155-166.

Berline, L., Spitz, Y.H., Ashjian, C.J., Campbell, R.G., Maslowski, W., and Moore, S.E. 2008. Euphausiid transport in the Western Arctic Ocean. Marine Ecology Progress Series 360:163-178.

Carroll, G.M., George, J.C., Lowry, L.F., and Coyle, K.O. 1987. Bowhead whale (Balaena mysticetus) feeding near Point Barrow, Alaska, during the 1985 spring migration. Arctic 40:105-110.

Clement, J.L., Maslowski, W., Cooper, L.W., Grebmeier, J.M., and Walczowski, W. 2005. Ocean circulation and exchanges through the northern Bering Sea: 1979-2001 model results. Deep-Sea Research II 52:3509-3540, doi:10.1016/j. dsr2.2005.09.010.

Corwith, H.L., and Wheeler, P.A. 2002. El Niño related variations in nutrient and chlorophyll distributions off Oregon. Progress in Oceanography 54:361-380.

Deines, K.L. 1999. Backscatter estimation using broadband acoustic Doppler current profilers. Proceedings of the IEEE Sixth Working Conference on Current Measurement. March 1999, 249-253, doi:10.1109/CCM.1999.755249.

Fleischbein, J., Hill, J., Huyer, A., Smith, R.L., and Wheeler, P.A. 1999. Hydrographic data from the GLOBEC long-term observation program off Oregon, 1997 and 1998. Data Report 172, Reference 99-1. Corvallis: Oregon State University.

Frost, K.J., and Lowry, L.F. 1984. Trophic relationships of vertebrate consumers in the Alaskan Beaufort Sea. In: Barnes, P.W., Schell, D.M., and Reimnitz, E., eds. The Alaskan Beaufort Sea. New York: Academic Press. 381-401.

George, J.C., Braund, S.R., Brower, H., Jr., and Nicolson, C.R. 2003. The influence of environmental conditions on the success of hunting bowhead whales off Barrow, Alaska. In:
McCartney, A., ed. Indigenous ways to the present. Edmonton, Alberta: Canadian Circumpolar Institute Press. 151-168.

Gordon, L.I., Jennings, J.C., Jr., Ross, A.A., and Krest, J.M. 1995. A suggested protocol for continuous flow automated analysis of seawater nutrients (phosphate, nitrate, nitrite and silicic acid) in the WOCE Hydrographic Programme and the Joint Global Ocean Fluxes Study. WOCE Operations Manual, WOCE Report No. 68/91. Revision 1995.

Hall, E.S., Dekin, A.A., and Cassedy, D.F. 1990. The Utqiagvik excavations. Barrow, Alaska: North Slope Borough Commission on Iñupiat History, Language, and Culture.

Johnson, M.W. 1958. Observations on inshore plankton collected during summer 1957 at Point Barrow, Alaska. Journal of Marine Research 17:172-181.

- 1963. Zooplankton collections from the high polar basin with special reference to the copepods. Limnology and Oceanography 8:89-102.

Kenney, R.D. 2001. Anomalous 1992 spring and summer right whale (Eubalaena glacialis) distributions in the Gulf of Maine. Journal of Cetacean Research Management (Special Issue) 2:209-223.

Krupnik, I., and Bogoslovskaya, L. 1999. Old records, new stories: Ecosystem variability and subsistence hunting in the Bering Strait area. Arctic Research of the United States 13:15-24.

Lowry, L.F. 1993. Foods and feeding ecology. In: Burns, J.J., Montague, J.J., and Cowles, C.J., eds. The bowhead whale. Society for Marine Mammalogy, Special Publication No. 2. Lawrence, Kansas: Allen Press. 201-238.

Lowry, L.F., and Sheffield, G. 2002. Stomach contents of bowhead whales harvested in the Alaskan Beaufort Sea. In: Richardson, W.J., and Thomson, D., eds. Bowhead whale feeding in the eastern Alaskan Beaufort Sea: Update of scientific and traditional information, Vol. 1. OCS Study MMS 2002-012; LGL Report TA2196-7. Report from LGL Ltd., King City, Ontario, for U.S. Minerals Management Service, Anchorage, Alaska, and Herndon, Virginia.

Lowry, L.F., Sheffield, G., and George, J.C. 2004. Bowhead whale feeding in the Alaskan Beaufort Sea, based on stomach contents analyses. Journal of Cetacean Research and Management 6:215-223.

Maslowski, W., Newton, B., Schlosser, P.B., Semtner, A.J., and Martinson, D.G. 2000. Modeling recent climate variability in the Arctic Ocean. Geophysical Research Letters 27(22): $3743-3746$.

Maslowski, W., Marble, D.C., Walczowski, W., and Semtner, A.J. 2001. On large scale shifts in the Arctic Ocean and sea ice conditions during 1979-1998. Annals of Glaciology 33: $545-550$.

Mayo, C.A., and Marx, M.K. 1990. Surface foraging behaviour of the North Atlantic right whale, Eubalaena glacialis, and associated zooplankton characteristics. Canadian Journal of Zoology 68:2214-2220.

Moore, S.E., and Laidre, K.L. 2006. Trends in sea ice cover within habitats used by bowhead whales in the Western Arctic. Ecological Applications 16:932-944.

Moore, S.E., and Reeves, R.R. 1993. Distribution and movement. In: Burns, J.J., Montague, J.J., and Cowles, C.J., eds. The 
bowhead whale. Society for Marine Mammalogy, Special Publication No. 2. Lawrence, Kansas: Allen Press. 313-386.

Moore, S.E., DeMaster, D.P., and Dayton, P.K. 2000. Cetacean habitat selection in the Alaskan Arctic during summer and autumn. Arctic 53:432-447.

Moore, S.E., George, J.C., Sheffield, G., Bacon, J., and Ashjian, C.J. 2010. Bowhead whale distribution and feeding near Barrow, Alaska, in late summer, 2005-06. Arctic 63:195-205.

Münchow, A., and Carmack, E.C. 1997. Synoptic flow and density observations near an Arctic shelf break. Journal of Physical Oceanography 27:1402-1419.

Niebauer, H.J., and Schell, D.M. 1993. Physical environment of the Bering Sea population. In: Burns, J.J., Montague, J.J., and Cowles, C.J., eds. Society for Marine Mammalogy, Special Publication No. 2. Lawrence, Kansas: Allen Press. 23-44.

Okkonen, S.R. 2008. Exchange between Elson Lagoon and the nearshore Beaufort Sea and its role in the aggregation of zooplankton, Final Report. OCS Study MMS 2008-010. Anchorage, Alaska: Minerals Management Service, Alaska OCS Region. 19 p.

Okkonen, S.R., Ashjian, C.J., Campbell, R.G., Maslowski, W., Kinney-Clement, J.L., and Potter, R. 2009. Intrusion of warm Bering/Chukchi waters onto the shelf in the western Beaufort Sea. Journal of Geophysical Research 114, C00A11, doi:10.1029/2008JC004870.

Paquette, R.G., and Bourke, R.H. 1974. Observations on the coastal current of Arctic Alaska. Journal of Marine Research 32:195-207.

Pickart, R.S., Weingartner, T.J., Pratt, L.J., Zimmerman, S., and Torres, D.J. 2005. Flow of winter-transformed Pacific Water into the Western Arctic. Deep-Sea Research II 52:3175-3198.

Proshutinsky, A.Y., and Johnson, M.A. 1997. Two circulation regimes of the wind-driven Arctic Ocean. Journal of Geophysical Research 102(C6):12493-12514.

. 2001. Two regimes of the Arctic's circulation from ocean models with ice and contaminants. Marine Pollution Bulletin 43:61-70.
Quakenbush, L.T., Citta, J.J., George, J.C., Small, R.J., and Heide-Jørgensen, M.P. In press. Fall and winter movements of bowhead whales (Balaena mysticetus) in the Chukchi Sea and within a potential petroleum development area. Arctic.

Schell, D.M., Barnett, B.A., and Vinnette, K.A. 1998. Carbon and nitrogen isotope ratios in zooplankton of the Bering, Chukchi and Beaufort seas. Marine Ecology Progress Series 172: $11-23$.

Sherr, E.B., Sherr, B.F., and Wheeler, P.A. 2005. Distribution of coccoid cyanobacteria and small eukaryotic phytoplankton in the upwelling ecosystem off the Oregon coast during 2001 and 2002. Deep-Sea Research II 52:317-330.

Signorini, S.R., Münchow, A., and Haidvogel, D. 1997. Flow dynamics of a wide Arctic canyon. Journal of Geophysical Research 102:18661-18680.

Stanford, D.J. 1976. The Walakpa Site, Alaska. Washington, D.C.: Smithsonian Institution Press.

Stoker, S.W., and Krupnik, I.I. 1993. Subsistence whaling. In: Burns, J.J., Montague, J.J., and Cowles, C.J., eds. Society for Marine Mammalogy, Special Publication No. 2. Lawrence, Kansas: Allen Press. 579-629.

Thompson, D.W.J., and Wallace, J.M. 1998. The Arctic Oscillation signature in the wintertime geopotential height and temperature fields. Geophysical Research Letters 25:1297-1300.

Weingartner, T.J., Cavalieri, D.J., Aagaard, K., and Sasaki, Y. 1998. Circulation, dense water formation, and outflow on the northeast Chukchi shelf. Journal of Geophysical Research 103:7647-7661.

Weingartner, T., Aagaard, K., Woodgate, R., Danielson, S., Sasaki, Y., and Cavalieri, D. 2005. Circulation on the north central Chukchi Sea shelf. Deep-Sea Research II 52:3150-3174.

Woodgate, R.A., and Aagaard, K. 2005. Revising the Bering Strait freshwater flux into the Arctic Ocean. Geophysical Research Letters 32, L02602, doi:10.1029/2004GL021747.

Woodgate, R.A., Aagaard, K., and Weingartner, T. 2005. A year in the physical oceanography of the Chukchi Sea: Moored measurements from autumn 1990-1991. Deep-Sea Research II 52:3116-3149. 